\title{
Dynamic Efficiency of Turkish Banks: a DEA Window and Malmquist Index Analysis for the Period of 2003-2012
}

\author{
Aziz KUTLAR, Department of Economics, Faculty of Political Sciences, Sakarya University, Turkey; e-mail: \\ akutlar@sakarya.edu.tr
}

Ali KABASAKAL, Department of Economics, Faculty of Political Sciences, Sakarya University, Turkey; e-mail: kabasakal@sakarya.edu.tr

Adem BABACAN, Department of Econometrics, Faculty of Economics and Administrative Sciences, Cumhuriyet University, Turkey; e-mail: ababacan@cumhuriyet.edu.tr

\section{Türkiye'deki Bankaların Dinamik Etkinliği: 2003-2012 Dönemi için VZA - Pencere ve Malmquist Endeksi Analizi}

\begin{abstract}
This article utilizes data envelopment analysis (DEA) in order to obtain technical efficiency and allocative efficiency scores of 23 commercial banks which operate in Turkey uninterruptedly between 2003 and 2012. According to results of CCR model analysis 3 banks are not technically efficient in the first years, the number of technically inefficient banks doubles in 2012. On the other hand the number of allocatively inefficient banks is only 5 in the first year and the number declines to 4 in the last year. The number of technically inefficient banks in the beginning is only one in terms of BCC model yet the number rose to 4 at the end of the study period. The relevant figure for allocative efficiency is 10 in the beginning and 16 at the end. DEA window analysis indicates that public banks with high amount of deposits tend to have higher efficiency scores while private banks have lower efficiency scores. The highest average in efficiency scores for all the banks occur in win 4 to win5 (2006-'09 to 2007-'10) period. The Malmquist Index is used to analyze total factor productivity and its increase merely by two thousandth $(0,002)$ for all the enterprises.
\end{abstract}

Keywords $\quad$ : Non-Parametric Method, Panel Data, DEA, TFP, Banking.

JEL Classification Codes : $\quad$ C14, C23, C44, D24, G21.

\section{$\ddot{\mathbf{O z}}$}

$\mathrm{Bu}$ çalışmada, 2003-2012 dönemi boyunca Türkiye'de faaliyette bulunan 23 ticari bankanın Teknik Etkinlik ve Tahsis Etkinliği skorları Veri Zarflama Analizi ile elde edilmiştir. CCR modeli ile yapılan analizde ilk yıl için toplam 3 banka etkin olmaz iken 2012 için bu sayı iki katına çıkmıştır. Tahsis etkinliği için ilk yılda 5 banka etkin görünmezken son yıl için bu sayı dörde düşmüştür. BCC modeli ile yapılan analizde ise dönem başında teknik etkinliğe sahip olmayan sadece bir banka varken dönem sonunda bu rakam 4'e çıkmaktadır. Tahsisi etkinliğine ilişkin rakamlar ise dönem başında 10iken dönem sonunda bu sayı 16 olmuştur. Dönem boyunca dinamik etkinliği ölçmek amaçlı uygulanan Veri Zarflama-Pencere Analizi sonuçlarına göre yüksek miktarda mevduata sahip kamu bankaları etkin fakat özel bankalar ise etkinsiz görünmektedirler. Tüm banlalar için ortalama etkinliğin en yüksek olduğu dönem 2006-2009 ile 2007-2010 dönemlerini kapsayan pencerelerde gerçekleşmektedir. Toplam faktör verimliliğine ilişkin düzenlenen Malmquist Endeksi analizi ile tüm bankalar göz önüne alındığında verimliliğin dönem boyunca sadece binde iki $(0,002)$ kadar arttığ görülmektedir. 
Kutlar, A. \& A. Kabasakal \& A. Babacan (2015), "Dynamic Efficiency of Turkish Banks: a DEA Window and Malmquist Index Analysis for the Period of 2003-2012", Sosyoekonomi, Vol. 23(24), 71-97.

\section{Introduction}

The increasing inflation and the uncontrollable increase in public debt in the 2000s forced Turkish banks to undergo some structural changes. The banking sector was seriously affected by the 2000/2001 financial crisis in Turkey. The number of banks was 79 in the beginning of this period however it went down to 55 in 2003 and to 49 in 2010 (Coşkun et al., 2012).

Following the crisis in February 2001, the transition to a free exchange rate policy allowed the Treasury to pay a nearly 19 billion dollar bill of "business loss" for the public banks. The management and the ownership of $20^{1}$ foreign banks (12 of them between 2000 and 2002) were transferred to the Banking Regulation and Supervision Agency by the Saving Deposit Insurance Fund, and investigations were launched against the owners and managers of these banks for corruption allegations. Some of these banks merged with other banks, some were sold, and some lost their licenses. Severe restrictions and regulations were imposed in banking system in order to prevent such problems in the future. One of these regulations is the Law numbered 5020 -put into effect in December 2003- which enables the Saving Deposit Insurance Fund to restructure and partially guarantee the deposits and another regulation is Basel II Criteria, which was put into effect in January 2008.

This study investigates the performance analysis of banks and the development of the Turkish banking sector in the last decade which coincides with the Justice and Development Party rule. The activities of the private, foreign and public banks operating in Turkey between 2003 and 2012, and their progress within the given period are discussed ${ }^{2}$. The banks analyzed in the study account for $99 \%$ of the total trading volume of all banks.

The efficiency of 23 commercial banks in Turkey is examined by data envelopment analysis (DEA) in our study. The data used in our study are obtained from the online databank of the Banks Association of Turkey and from the corporate websites of the banks. The data of more than 30 banks are pre-examined. Data including seven inputs and

1 Total number of commercial banks was 62 in 1999 and 19 of them were foreign-invested banks. The number of commercial banks went down to 41 in 2003 and 13 of the relevant banks were foreign-invested.

2 The following changes are observed in the banks we have studied. Sitebank continued its operations as Bankeuropa as of the first quarter of 2003 then changed to Millenium Bank in the last quarter of 2006 and finally continues its operations as Fibabanka since the second quarter of 2011. Türk Dıș Ticaret Bankasl (Turkish Foreign Trade Bank) became Fortis Bank as of the last quarter of 2005 then merged with the Türk Ekonomi Bankası (TEB) as of the first quarter of 2011. Koçbank merged with Yapı Kredi as of the last quarter of 2006. MNG Bank became TurkLand Bank as of the first quarter of 2007. Oyak Bank continued its operations as ING Bank as of the fourth quarter of 2008. Tekfen Bank became Eurobank Tekfen as of the first quarter of 2008 and continues operations as BURGANBANK since the last quarter of 2012. 
five outputs are used. Comprehensive information on the relevant inputs and outputs are given in the empirical findings section.

Table: 1

Some Figures about the Commercial Banks in Turkey for the Years 2003 \& 2012

\begin{tabular}{|c|c|c|c|c|c|c|c|c|}
\hline Banks & $\begin{array}{r}\text { Net Assets } \\
, 03\left(10^{3} \mathrm{TL}\right)\end{array}$ & $\begin{array}{r}\text { Deposits } \\
, 03\left(10^{3} \text { TL }\right)\end{array}$ & $\begin{array}{r}\text { Salaries } \\
, 03\left(10^{3} \mathrm{TL}\right)\end{array}$ & $\begin{array}{r}\text { \# of Personnel } \\
{ }_{03}\end{array}$ & $\begin{array}{r}\text { Net Assets } \\
, 12\left(10^{3} \mathrm{TL}\right)\end{array}$ & $\begin{array}{r}\text { Deposits } \\
, 12\left(10^{3} \mathrm{TL}\right)\end{array}$ & $\begin{array}{r}\text { Salaries } \\
, 12\left(10^{3} \mathrm{TL}\right)\end{array}$ & $\begin{array}{r}\text { \# of Personnel } \\
{ }_{12}\end{array}$ \\
\hline AKBANK & 25731306 & 19103202 & 267496 & 9625 & 81838295 & 86104718 & 2589653 & 16072 \\
\hline ABank & 979566 & 723658 & 23524 & 487 & 6857444 & 4176060 & 114001 & 1191 \\
\hline Anadolubank & 1444327 & 1147913 & 59768 & 879 & 5980496 & 3921371 & 195301 & 1963 \\
\hline Fibabanka & 100685 & 60103 & 15682 & 186 & 3582198 & 2689441 & 86734 & 532 \\
\hline Șekerbank & 2518486 & 2059865 & 73834 & 3009 & 13578241 & 10137906 & 262077 & 3554 \\
\hline TEKSTİLBANK & 1020322 & 744747 & 23910 & 866 & 3418609 & 2715425 & 64995 & 852 \\
\hline TURKISHBANK & 359602 & 290166 & 5539 & 184 & 863575 & 616814 & 19049 & 288 \\
\hline TEB & 6631968 & 4725993 & 154650 & 4893 & 37475724 & 28726565 & 634396 & 9235 \\
\hline Garanti & 19451324 & 14400740 & 754322 & 7971 & 133926932 & 87482419 & 2772294 & 17208 \\
\hline Türkiye İş Bankası & 28212226 & 19561606 & 621060 & 15415 & 161022637 & 105383434 & 3042824 & 24580 \\
\hline Yap1Kredi & 26099862 & 18477991 & 453258 & 13701 & 104382239 & 68043940 & 2413358 & 14908 \\
\hline Sum of Private & 112549674 & 81295984 & 2453043 & 57216 & 552926390 & 399998093 & 12194682 & 90383 \\
\hline $\begin{array}{r}\text { Sum of Private / } \\
\text { Grand Total }\end{array}$ & 0.53 & 0.52 & 0.58 & 0.51 & 0.53 & 0.52 & 0.62 & 0.51 \\
\hline A\&T Bank & 126067 & 35589 & 12021 & 176 & 1489853 & 1029738 & 43976 & 268 \\
\hline BURGAN BANK & 557587 & 432417 & 19434 & 589 & 4193685 & 3264555 & 82226 & 962 \\
\hline Citibank & 1175374 & 823895 & 52231 & 1119 & 7409809 & 5171532 & 174951 & 2123 \\
\hline DenizBank & 4370644 & 3092064 & 71529 & 3086 & 38081429 & 26696342 & 569065 & 10368 \\
\hline Deutsche Bank & 121284 & 0 & 25681 & 31 & 1058652 & 430740 & 25116 & 107 \\
\hline FINANSBANK & 4676925 & 3635026 & 100250 & 3539 & 50608866 & 32921506 & 1342609 & 11330 \\
\hline HSBC & 3264702 & 2098536 & 160503 & 3439 & 19068172 & 14206411 & 511365 & 6023 \\
\hline ING BANK & 4195886 & 3513724 & 113145 & 3791 & 18908477 & 14430196 & 416108 & 5245 \\
\hline TBANK & 217852 & 139444 & 6132 & 189 & 2380632 & 1879282 & 57553 & 498 \\
\hline Sum of Foreign & 18706321 & 13770695 & 560926 & 15959 & 143199575 & 100030302 & 3222969 & 36924 \\
\hline $\begin{array}{r}\text { Sum of Foreign / } \\
\text { Grand Total }\end{array}$ & 0.09 & 0.09 & 0.13 & 0.14 & 0.14 & 0.13 & 0.16 & 0.21 \\
\hline Ziraat Bankası & 46057835 & 33851826 & 655596 & 22440 & 158637835 & 118966304 & 1361181 & 23766 \\
\hline HALKBANK & 18950836 & 13820883 & 278004 & 8692 & 99774884 & 79973901 & 870456 & 14131 \\
\hline VakıfBank & 15482525 & 12698961 & 257539 & 7446 & 94881178 & 67242290 & 2168815 & 13064 \\
\hline Sum of Public & 80491196 & 60371670 & 1191139 & 38578 & 353293897 & 266182495 & 4400452 & 50961 \\
\hline $\begin{array}{r}\text { Sum of Public / } \\
\text { Grand Total }\end{array}$ & 0.38 & 0.39 & 0.28 & 0.35 & 0.34 & 0.35 & 0.22 & 0.29 \\
\hline Grand Total & 211747191 & 155438349 & 4205108 & 111753 & 1049419862 & 766210890 & 19818103 & 178268 \\
\hline Change in Private & 1 & 1 & 1 & 1 & 4.91 & 4.92 & 4.96 & 1.57 \\
\hline Change in Foreign & 1 & 1 & 1 & 1 & 10.40 & 7.26 & 5.75 & 2.31 \\
\hline Change in Public & 1 & 1 & 1 & 1 & 4.39 & 4.41 & 3.69 & 1.32 \\
\hline
\end{tabular}

Table 1 provides information on the structure of and the changes in the banks in Turkey. There are 23 banks in the table; 11 of them are private, 9 of them are foreign and 3 of them are public banks. The total deposit of these banks was 155 billion TL in 2003 and the amount rose fivefold with 766 billion TL in 2012. In the same period, the net asset value increased at the same rate. We observe that the rate of increase in the number of employees remain constant around $60 \%$.

In the relevant period, we observe significant changes in terms of capital. The share of private banks in the total bank deposits remained constant by $52 \%$ for the last ten years. The share of foreign bank deposits in the total bank deposits increased from $9 \%$ to $13 \%$ whereas it decreased from $39 \%$ to $35 \%$ for public banks. In addition, the deposit shares of the foreign banks increased by $44 \%$ and the deposit shares of public banks decreased by $10 \%$. 
Looking at the number of employees, it is apparent that the share of the employees working in private banks remained constant by $51 \%$ for ten years. However, the share of the employees working in foreign banks increased from $14 \%$ to $21 \%$ in comparison with the total number of employees, but the relevant figure decreased from $34 \%$ to $29 \%$ in public banks. In short, out of ten bank employees every 5 work in a private bank while 3 work in public bank and 2 in foreign-invested banks.

Ziraat Bank held $22 \%$ of the total deposit in 2003 and $16 \%$ of the total deposit in 2012. Ziraat Bank employed $20 \%$ of the employees in the beginning of the given period and 13\% in 2012. Türkiye İş Bankası and AKBANK follow Ziraat Bankası. Deutsche Bank has the least deposit and the least number of employees.

Our paper unfolds as follows. Literature review is given in the following section. A brief explanation is given on methodology in section 3 including DEA, Window Analysis and Malmquist Index (MI). The empirical results of the analyses are found in section 4 . Finally, the conclusion and the suggestions are presented in the last section.

\section{Literature}

The majority of the studies on banking efficiency use DEA and Malmquist Index. A series of models in different time segments with various input and output variables are employed in DEA analyses to investigate efficiency of the banks. Avkiran (2011) lists only some of these studies; however all of the studies are worth mentioning.

Das and Ghosh (2006) investigate the efficiency of the Indian Banks over a ten year period between 1992 and 2002. They adopt three different approaches -intermediation, value-added and DEA approach- in order to define inputs and outputs of the analysis. Their findings suggest that the Technical Efficiency (TE) scores seem to be higher according to the value-added approach and intermediation approach indicates that efficiency scores are low and they decline over the years. The banks with low-risk portfolios and lower nonperforming loans are more efficient as well.

Staub et al. (2010) investigate the efficiency scores of the Brazilian banking in the period 2000-2007 using DEA and claim that the efficiency scores are lower than other countries. They also claim that the foreign banks in Brazil are less cost efficient and the state-owned banks are relatively more efficient.

Avkiran (2011) investigates the relationship between DEA efficiency scores of a bank and the performance ratios of the Chinese banks in 2007 and 2008 but the results indicate an inadequate correlation between them. Further investigations on how DEA is utilized to select the ratio benchmarks for firm groups imply that for firm based 
standardization, stock pricing, and regulatory purposes are the areas that ratio benchmarking may be utilized to predict the future values of some financial ratios via efficiency estimates.

Yang (2011) uses an enhanced DEA model to investigate the efficiency of the Taiwanese banking industry. The findings suggest that the banks associated with financial holding companies are doing better and the lack of TE mainly results from operating inefficiency.

Pasiouras (2008) employs DEA to explore the efficiency of the Greek commercial banking industry over the period 2000-2004. He claims that higher capitalization, loan activity, market power and the number of branches increase efficiency of banks.

Havranek and Irsova (2013) examine and compare the efficiency of the banks in the Czech Republic, Hungary, Poland, Slovenia, Slovakia and the USA for the period 19952006. They also examine how different specifications of DEA change the results. They argue that foreign banks operating in transition countries are more efficient. Another finding is that while large banks in the USA are definitely performing better, the results for the remaining Central European and Eastern European countries depend on the way DEA is designed.

Paradin and Zhu (2013) investigate 80 published DEA applications in 24 countries that emphasize bank branches. They discuss the key issues in designing DEA models in the relevant studies. They make suggestions on how to design DEA for further experiments.

Sufian (2006) investigates the long term trend of efficiency change in Malaysian commercial banks for the period 1992-2003 using DEA window analysis. According to his findings banks exhibits an average efficiency of $90.4 \%$, and small banks outperform larger ones on scale efficiencies whereas large banks have higher pure TE scores.

Asmild et al. (2004) implements DEA and MI analyses of Canadian banks between 1981 and 2000 with a 5-year window width. Since five large banks dominate Canadian banking system (around 90\%), evaluating the performance of the system imply dealing with few DMUs but greater number of input and output variables.

Sufian and Abdulmajid (2007a) investigate the effects of mergers and acquisitions on efficiency of the Singapore banking group using 3-year window analysis and DEA. The study indicates that mergers generate higher efficiency scores. The study suggests that the efficiency of banking groups is around $91.68 \%$; however, there is a slight decline $(90.8 \%)$ during the merger period due to scale inefficiency.

Sufian and Abdulmajid (2007b) investigate efficiency change of commercial banks in Singapore for the period 1993-2003 using non-parametric DEA window analysis. According to their findings the relevant banks exhibit an average efficiency of $95.4 \%$. They 
also found that small banks outperform the larger ones. They performed a panel regression analysis between performance of the banks and performance of their share price. Their finding suggest that cost efficiency affects stock prices of the Singapore banks and therefore improvements in cost efficiency improve stock performance of the banks.

Isik and Hassan (2003) used DEA and MI in their study in order to investigate the impact of financial reforms introduced in the 1980s on the productivity, efficiency and technology of Turkish commercial banks between 1981 and 1990. They report that all the banks experienced high productivity gains driven mostly by efficiency increases rather than technical progress, and efficiency increase did not result from scale increase but renewed management practices. The study suggests that the performance gap between the banks is slowly disappearing. They also confirm that foreign banks are relatively more efficient than domestic banks.

Mercan et al. (2003) present a financial performance index for Turkish commercial banks to observe the effects of scale and the mode of ownership on bank behavior and performance for the period 1989-99. Their study indicates that state-owned banks are outperformed by foreign and private banks in terms of efficiency, and large scale banks seem to perform better than small or medium sized banks.

Denizer et al. (2007) examine the banking efficiency in Turkey between 1970 and 1994, a period of liberalization, by employing DEA. The fact that fluctuating inflation and economic growth reduces bank efficiency suggest that macroeconomic factors are important for bank efficiency. The banking sector utilizes the sources poorly; the commercial banks could have either reduced all of their inputs and/or produced more outputs.

Fukuyama and Matousek (2011) make a variable returns to scale efficiency analysis of cost efficiency, TE and allocative efficiency (AE) of the Turkish banks between 1991 and 2007. They argue that the results of their study reflect the picture of the Turkish economy before and after the 2001 financial crises from 1994 to 2001. According to their findings restructuring and consolidation processes implemented after the crisis have had positive effects. They also point out that there is a gap between the best and the worst banks in the industry, and foreign banks do not necessarily outperform the rest in efficiency unlike the ones in the new EU countries.

Unvan and Tatlidil (2012) investigate the performance of the Turkish banking industry for the period 2002-2008 by using DEA and MI for total factor productivity (TFP). They report that the industry faces efficiency loss from 2005 to 2008 and medium-sized banks are the most efficient ones. 


\section{Methodology}

Debreu (1951), Koopmans (1951) and Farrell (1957) are prominent scholars to use efficiency analysis in the economic literature. Following their footprints the number of studies devoted to measurement of efficiency has increased. Use of frontier functions is an important part of measurement of efficiency.

The parametric approach contains deterministic and stochastic models. In nonparametric analysis as in Charnes, Cooper, and Rhodes (CCR) (1979) the specification of any particular functional form is not necessary to define the efficient frontier or envelopment surface.

\subsection{Structure of DEA and Efficiency}

Efficiency may be defined as an effort to obtain the highest output possible by preferring the method that uses the input composition in the most productive way. Methodology used to obtain TE and AE scores is the same as Kutlar et al. (2013). Assuming a decision making unit (DMU) generates the outputs $y_{i},(i=1,2, \ldots, t)$ from the inputs $x_{k}$, $(k=1,2, \ldots, m)$, the equation can be expressed in the following way by help of the appropriate weights $\left(v_{i}=1,2, \ldots, t ; w_{k}=1,2, \ldots, m\right)$ on the variables:

$$
\sum_{i=1}^{t} v_{i} y_{i} / \sum_{k=1}^{m} w_{k} x_{k}
$$

Fractional program utilizes the TFP rate. In other words, DEA should be considered as a conceptual model and the linear model as a practical method in the efficiency calculations. In DEA, weights are determined pertaining to DMUs for each variable.

DEA takes the inputs (xk) and outputs (yi) in the equation given above and selects the weights that maximize performance of the DMU "p" related to the performances of other units:

$$
\operatorname{Max} v_{i} w_{k}\left(\sum_{i=1}^{t} v_{i} y_{i p} / \sum_{k=1}^{m} w_{k} x_{k p}\right)
$$

follows:

Here, the efficiency value of " $z$ " number DMUs under the $\leq 1$ constraint is as 


$$
0 \leq \sum_{i=1}^{t} v_{i} y_{i c} / \sum_{k=1}^{m} w_{k} x_{k c} \leq 1(\mathrm{c}=1,2, \ldots, \mathrm{p}, \ldots, \mathrm{z} ; \mathrm{vi}=1,2, \ldots, \mathrm{t} ; \mathrm{wk}=1,2, \ldots, \mathrm{m})(3)
$$

In the model, " $v$ " and " $w$ " constitute the weight on the inputs and outputs and variables in the equation. Solution of the model gives an efficiency value of " $p$ " DMU and a set of necessary weights to reach this value. Solution of non-parametric efficiency measurement model in the form of fractional programming form was converted to the linear programming model easier to solve (Charnes et al., 1978, 1979; Banker et al., 1984).

\subsection{Window Analysis}

In DEA analysis if the amount of DMU is limited in comparison to the number of input and output variables some problems may arise due to the lower degree of freedom. In order to overcome such problems, one may consider collecting a panel data to use with DEA window analysis method (Cooper et al. 2006). Average Efficiency of a DMU may fluctuate over time and capturing these variations is possible with DEA window analysis as proposed by Charnes et al. (1985). In that way performance comparisons of a DMU in a specific time slot with the same DMU in other time period and with another DMU in the same period can be made. This analysis evaluates the performance of a DMU over time by assuming the DMU is a different unit in each period.

The methodology used evaluating panel dataset with DEA comes from Tulkens and Eeckaut (1995). A k sized window $k \epsilon\{1,2 \ldots \ldots n ; n<m\}$ at time $\mathrm{t}$ can be illustrated as a subset of adjacent time points $T^{k t}=\{\gamma \mid \gamma=t, t+1 \ldots, t+k ; t<m-k\}$. Observed values of this window can be used to build a production set with an intertemporal reference, representing the period of time $[t, t+k]$. Generating sequential windows, defined for $t=1$, $2, \ldots, m-k$, creates a series of reference non-nested sets of production. The purpose of treating time series in window analysis averages over the time periods defined by the window.

Having a narrow window size may lead to a fewer number of DMUs and this combined with large numbers of variables diminish the discriminatory power of the analysis. Having larger window size however, may provide misleading outcomes since any important change happening over time may be covered by more windows (Cooper et al. (2011).

Although there seems to be no theory or justification, a window width of three years is commonly used by scholars such as Charnes et al. (1985), Avkiran (2004), Webb (2003), and Sufian and Abdulmajid (2007a, 2007b). Some other studies (Asmild et al., 2004) utilize more than 3 years as window width, though. 


\subsection{Malmquist Index}

Malmquist productivity Index is one of the indices that investigate change in the production (Malmquist, 1953). Used in DEA by Caves et al. (1982), this index consists of difference functions representing multi-output and multi-input technologies based on the input and output quantities.

The index can be calculated by parametrical and linear programming methods. Two functions are obtained by the use of DEA. One of these functions expresses the technical change and the other one deals with the change in TE (Liu and Wang, 2008). MI can be calculated either as input oriented or output oriented. A production oriented Malmquist TFP change index $\mathrm{M}_{\mathrm{h}}{ }^{\mathrm{t}+1}$ can be expressed in the following way:

$$
M_{h}^{t+1}\left(X_{h}^{t+1}, Y_{h}^{t+1}, X_{h}^{t}, Y_{h}^{t}\right)=\left[\frac{D_{h}^{t}\left(X^{t+1}, Y^{t+1}\right)}{D_{h}^{t}\left(X^{t}, Y^{t}\right)} \frac{D_{h}^{t+1}\left(X^{t+1}, Y^{t+1}\right)}{D_{h}^{t+1}\left(X^{t}, Y^{t}\right)}\right]^{1 / 2}
$$

This index can be written in two different ways:

$$
M_{o}\left(x^{t+1}, y^{t+1}, x^{t}, y^{t}\right)=\overbrace{\frac{D_{o}^{t+1}\left(x^{t+1}, y^{t+1}\right)}{D_{o}^{t}\left(x^{t}, y^{t}\right)}}^{E C} \overbrace{\left[\left(\frac{D_{o}^{t}\left(x^{t+1}, y^{y+1}\right)}{D_{o}^{t+1}\left(x^{t+1}, y^{t+1}\right)}\right)\left(\frac{D_{o}^{t}\left(x^{t}, y^{t}\right)}{D_{o}^{t+1}\left(x^{t}, y^{t}\right)}\right)\right]^{0.5}}^{T C}
$$

The part of index outside the brace indicates proportional efficiency change between two periods, and the index inside the brace indicates TE change. This equation can be defined in two parts as follows:

$$
\begin{aligned}
& \text { Efficiency Change }(E C)=\frac{D_{o}^{t+1}\left(x^{t+1}, y^{t+1}\right)}{D_{o}^{t}\left(x^{t}, y^{t}\right)} \\
& \text { Technical Change }(T C)=\left[\left(\frac{D_{o}^{t}\left(x^{t+1}, y^{y+1}\right)}{D_{o}^{t+1}\left(x^{t+1}, y^{t+1}\right)}\right)\left(\frac{D_{o}^{t}\left(x^{t}, y^{t}\right)}{D_{o}^{t+1}\left(x^{t}, y^{t}\right)}\right)\right]^{0.5}
\end{aligned}
$$

If there is a need to express it briefly, MI is defined as;

$$
M_{o}^{t, t+1}=E C^{t, t+1} T C^{t, t+1}
$$


The equation above shows the production element of $D_{h}$ in the period $t$ and $t+1$. Taking the technology in the period of $t$ as reference, the period $t+1$ is used. Reference category can be selected arbitrarily. Here, the DMUs being $(h=1,2, \ldots . .23)$ the input vector is $x_{h}^{t}=\left(X_{1 h t}, X_{2 h t}, \ldots ., X_{7 h t}\right)^{\prime}$ and the output vector is $y_{h}^{t}=\left(Y_{1 h t}, Y_{2 h t}, \ldots ., Y_{5 h t}\right)^{\prime}$.

\section{Empirical Findings}

In Turkey, some banks ceased operations or management and ownership of some banks were transferred to the state before and following the 2001 financial crisis. Following these negative changes in the banking sector, a series of legal arrangements and structural changes have taken place. Following such arrangements we implemented the activity analysis of private, foreign and public banks which were active between 2003 and 2012 in Turkey.

Table 2 indicates the descriptive statistics of the inputs and the outputs which comprises of 230 data from the years between 2003 and 2012. The net assets variable has the highest values and the deposit variable has the highest standard deviations. As given in the table, seven inputs and five outputs are used. The number of inputs used in our study outnumbers several other studies. For instance, in their analysis of Turkish banking sector; Isik and Hassan (2003) applied three-input and four-output variables, Mercan et al. (2003) applied two-input and three-output variables in order to obtain efficiency scores of the banks by using the CAMEL model, on the other hand Fukuyama and Matousek (2011) used twoinput and two-output variables. In this respect, the number of input and output variables is one of the highlights of this study.

Another remarkable point of this study is that TE and AE data are evaluated over a ten-year period. Economic efficiency data is not stated here again since it is a multiplication of these two data outputs. After comparing TE and AE, we aim to determine the outputs which have corrective or detractive (reducing) effects on these scores by using econometric method. While determining the efficiency scores by data development analysis, the surplus of the inputs and the scarcity of the outputs are determined by using input-oriented or outputoriented models. TE and AE are calculated by using input-oriented CCR model with constant returns to scale and input-oriented Banker, Charnes, and Cooper (BCC) (1984) model with variable returns to scale. Thus, it will be possible to observe the success of the econometric method in determining the efficiency scores. In this study, CCR model with constant returns to scale and $\mathrm{BCC}$ model with variable returns to scale are used to apply the efficiency analysis and the results are evaluated.

Technical and allocative efficiency of 23 banks determined by the CCR model are given in Table 3. According to the data 3 banks alone did not have TE as of 2003 on the other hand 18 banks did not have AE in the same year. After ten years, the number of banks without TE raised to 6 while the number of those without AE declined to 19. According to 
the results of CCR model analysis approximately $25 \%$ of the banks did not have TE and 80 $\%$ did not have $\mathrm{AE}$ at the end of the study period.

Table: 2

\section{Descriptive Statistics}

\begin{tabular}{|c|c|c|c|c|c|c|c|}
\hline \multicolumn{8}{|c|}{ Input Variables } \\
\hline & Net Assets & Deposits & $\begin{array}{c}\text { Interest } \\
\text { Expenses }\end{array}$ & $\begin{array}{c}\text { Paid Fees \& } \\
\text { Commissions } \\
\end{array}$ & $\begin{array}{c}\text { Other Operations } \\
\text { Expenses }\end{array}$ & Salaries & $\begin{array}{c}\text { \# of } \\
\text { Personnel } \\
\end{array}$ \\
\hline & $\begin{array}{c}\mathrm{NA}_{\mathrm{t}} \\
\left(10^{3} \mathrm{TL}\right)\end{array}$ & $\begin{array}{c}\mathrm{D}_{\mathrm{t}^{*}} \\
\left(10^{3} \mathrm{TL}\right)\end{array}$ & $\begin{array}{c}\mathrm{IE}_{\mathrm{t}} \\
\left(10^{3} \mathrm{TL}\right)\end{array}$ & $\begin{array}{c}\mathrm{PFC}_{\mathrm{t}} \\
\left(10^{3} \mathrm{TL}\right) \\
\end{array}$ & $\begin{array}{c}\mathrm{OOE}_{\mathrm{t}} \\
\left(10^{3} \mathrm{TL}\right) \\
\end{array}$ & $\begin{array}{c}\mathrm{EP}_{\mathrm{t}} \\
\left(10^{3} \mathrm{TL}\right) \\
\end{array}$ & $\mathrm{NE}_{\mathrm{t}}$ \\
\hline Mean & 25378547 & 18702235 & 1648393. & 75666.51 & 808383.6 & 468628.9 & 6453.922 \\
\hline Median & 7116006 & 5383741. & 547408.0 & 23857.50 & 421856.5 & 174974.0 & 3917.500 \\
\hline Maximum & 161022637 & 125796472 & 9265832 . & 484484.0 & 4484306 . & 3042824 . & 24698.00 \\
\hline Minimum & 100685.0 & $0.000000^{* *}$ & 1977.000 & 123.0000 & 12297.00 & 5539.000 & 31.00000 \\
\hline Std. Dev. & 36182789 & 26544578 & 2142331 . & 103980.4 & 922191.3 & 647457.3 & 6673.656 \\
\hline Skewness & 1.860786 & 1.835844 & 1.453638 & 1.716521 & 1.355067 & 2.056589 & 0.954138 \\
\hline Kurtosis & 5.954249 & 5.873940 & 4.211071 & 5.526248 & 4.315798 & 6.863161 & 2.907148 \\
\hline Jarque-Bera & 216.3695 & 208.3495 & 95.05660 & 174.1072 & 86.97973 & 305.1548 & 34.98049 \\
\hline Probability & 0.000000 & 0.000000 & 0.000000 & 0.000000 & 0.000000 & 0.000000 & 0.000000 \\
\hline Sum & $5.84 \mathrm{E}+09$ & $4.30 \mathrm{E}+09$ & $3.79 \mathrm{E}+08$ & 17403298 & $1.86 \mathrm{E}+08$ & $1.08 \mathrm{E}+08$ & 1484402. \\
\hline $\begin{array}{l}\text { Sum Sq. } \\
\text { Dev. }\end{array}$ & $3.00 \mathrm{E}+17$ & $1.61 \mathrm{E}+17$ & $1.05 \mathrm{E}+15$ & $2.48 \mathrm{E}+12$ & $1.95 \mathrm{E}+14$ & $9.60 \mathrm{E}+13$ & $1.02 \mathrm{E}+10$ \\
\hline Observations & 230 & 230 & 230 & 230 & 230 & 230 & 230 \\
\hline \multicolumn{8}{|c|}{ Output Variables } \\
\hline & & $\begin{array}{c}\text { Credits } \\
\& \\
\text { Lendings }\end{array}$ & $\begin{array}{l}\text { Operational } \\
\text { Income }\end{array}$ & Interest Income & $\begin{array}{l}\text { Received Fees \& } \\
\text { Commissions }\end{array}$ & $\begin{array}{c}\text { Other Operational } \\
\text { Income }\end{array}$ & \\
\hline & & $\begin{array}{c}\mathrm{CL}_{\mathrm{t}} \\
\left(10^{3} \mathrm{TL}\right)\end{array}$ & $\begin{array}{c}\mathrm{OI}_{\mathrm{t}} \\
\left(10^{3} \mathrm{TL}\right)\end{array}$ & $\begin{array}{c}\mathrm{II}_{\mathrm{t}} \\
\left(10^{3} \mathrm{TL}\right)\end{array}$ & $\begin{array}{c}\mathrm{RF}_{\mathrm{t}} \\
\left(10^{3} \mathrm{TL}\right)\end{array}$ & $\begin{array}{c}\mathrm{OOI}_{\mathrm{t}} \\
\left(10^{3} \mathrm{TL}\right)\end{array}$ & \\
\hline & Mean & 14564021 & 1822634. & 2867636 . & 406773.9 & 189471.6 & \\
\hline & Median & 4606351. & 724946.0 & 1023517. & 140404.0 & 76464.50 & \\
\hline & Maximum & 107142154 & 9814381. & 14810669 & 2492089 . & 1569284 . & \\
\hline & Minimum & 3407.000 & 7103.000 & 6147.000 & 178.0000 & 72.00000 & \\
\hline & Std. Dev. & 21201439 & 2285100 . & 3619745. & 554293.8 & 273969.7 & \\
\hline & Skewness & 1.995168 & 1.415212 & 1.392579 & 1.726893 & 2.215921 & \\
\hline & Kurtosis & 6.638678 & 4.062367 & 3.981325 & 5.451587 & 8.270153 & \\
\hline & Jarque-Bera & 279.4765 & 87.59097 & 83.56763 & 171.9146 & 454.4008 & \\
\hline & Probability & 0.000000 & 0.000000 & 0.000000 & 0.000000 & 0.000000 & \\
\hline & Sum & $3.35 \mathrm{E}+09$ & $4.19 \mathrm{E}+08$ & $6.60 \mathrm{E}+08$ & 93557998 & 43578464 & \\
\hline & $\begin{array}{l}\text { Sum Sq. } \\
\text { Dev. }\end{array}$ & $1.03 \mathrm{E}+17$ & $1.20 \mathrm{E}+15$ & $3.00 \mathrm{E}+15$ & $7.04 \mathrm{E}+13$ & $1.72 \mathrm{E}+13$ & \\
\hline & Observations & 230 & 230 & 230 & 230 & 230 & \\
\hline
\end{tabular}

$*(t=03,04, \ldots, 12)$

** Deutsche Bank did not accept deposits before 2004 and therefore there is only one zero value for the variable of Deposits.

Some of the banks are observed to be inefficient in terms of AE during the entire period. The year 2008 is the most effective year for all the banks. In 2011 and 2012 banks have the lowest performance. Fibabanka has the lowest rates in terms of efficiency within the given period. The AE score of Fibabanka is $19 \%$ in 2003 . Even though the number of the efficient banks decreased, the efficiency scores increased. 
Table: 3

TE and AE Scores of 23 DMU According to the CCR Method

\begin{tabular}{|c|c|c|c|c|c|c|c|c|c|c|c|c|c|c|c|c|c|c|c|c|}
\hline Company & $\mathrm{TE}_{03}$ & $\mathrm{AE}_{03}$ & $\mathrm{TE}_{04}$ & $\mathrm{AE}_{04}$ & $\mathrm{TE}_{05}$ & $\mathrm{AE}_{05}$ & $\mathrm{TE}_{06}$ & $\mathrm{AE} 306$ & $\mathrm{TE}_{07}$ & $\mathrm{AE}_{07}$ & TE08 & $\mathrm{AE}_{08}$ & $\mathrm{TE}_{09}$ & $\mathrm{AE}_{09}$ & $\mathrm{TE}_{10}$ & $\mathrm{AE}_{10}$ & $\mathrm{TE}_{11}$ & $\mathrm{AE}_{11}$ & $\mathrm{TE}_{12}$ & $\mathrm{AE}_{12}$ \\
\hline AKBANK & 1 & 0.654 & 1 & 0.778 & 1 & 0.674 & 1 & 0.818 & 1 & 0.880 & 1 & 0.753 & 1 & 0.677 & 1 & 0.727 & 1 & 0.739 & 1 & 1 \\
\hline ABank & 1 & 0.814 & 1 & 1 & 1 & 1 & 1 & 1 & 1 & 1 & 1 & 0.879 & 1 & 1 & 1 & 1 & 1 & 0.830 & 1 & 0.834 \\
\hline Anadolubank & 1 & 0.664 & 1 & 0.700 & 0.862 & 0.795 & 0.947 & 0.890 & 1 & 0.970 & 0.995 & 0.861 & 0.964 & 0.846 & 1 & 0.867 & 0.980 & 0.862 & 0.937 & 0.829 \\
\hline A\&T Bank & 1 & 1 & 1 & 1 & 1 & 0.956 & 1 & 1 & 1 & 1 & 1 & 1 & 1 & 1 & 1 & 1 & 1 & 0.656 & 1 & 0.663 \\
\hline BURGAN BANK & 0.924 & 0.742 & 1 & 0.708 & 1 & 0.625 & 1 & 0.638 & 1 & 0.962 & 1 & 0.931 & 1 & 0.871 & 1 & 0.930 & 1 & 0.846 & 0.907 & 0.811 \\
\hline Citibank & 1 & 1 & 1 & 0.889 & 1 & 1 & 1 & 0.505 & 1 & 1 & 1 & 0.897 & 1 & 1 & 1 & 0.933 & 0.846 & 0.884 & 1 & 1 \\
\hline DenizBank & 1 & 0.655 & 1 & 0.752 & 0.940 & 0.860 & 1 & 0.850 & 0.986 & 0.949 & 1 & 1 & 1 & 1 & 1 & 1 & 1 & 1 & 1 & 0.775 \\
\hline Deutsche Bank & 1 & 1 & 1 & 1 & 1 & 1 & 0.974 & 0.872 & 1 & 1 & 1 & 1 & 1 & 1 & 1 & 0.460 & 1 & 1 & 1 & 1 \\
\hline Fibabanka & 0.497 & 0.192 & 0.672 & 0.754 & 0.905 & 0.658 & 1 & 0.638 & 1 & 0.661 & 1 & 0.830 & 1 & 0.773 & 0.869 & 0.845 & 1 & 0.889 & 1 & 0.853 \\
\hline FINANSBANK & 1 & 1 & 1 & 1 & 1 & 1 & 1 & 1 & 1 & 1 & 1 & 0.991 & 1 & 0.888 & 1 & 0.899 & 1 & 0.937 & 1 & 0.786 \\
\hline HSBC & 1 & 1 & 1 & 0.972 & 1 & 0.931 & 1 & 1 & 1 & 1 & 1 & 1 & 1 & 1 & 1 & 1 & 1 & 1 & 0.974 & 0.891 \\
\hline ING BANK & 1 & 0.972 & 1 & 0.967 & 1 & 0.836 & 1 & 0.771 & 0.944 & 0.950 & 1 & 0.946 & 1 & 1 & 1 & 1 & 1 & 1 & 1 & 1 \\
\hline Şekerbank & 1 & 0.661 & 1 & 1 & 1 & 1 & 1 & 0.960 & 1 & 1 & 1 & 1 & 1 & 0.937 & 0.993 & 0.858 & 1 & 0.859 & 1 & 0.917 \\
\hline TEKSTILBANK & 1 & 0.895 & 1 & 0.970 & 1 & 0.917 & 1 & 0.925 & 1 & 1 & 1 & 1 & 0.989 & 0.922 & 1 & 0.777 & 0.984 & 0.782 & 0.977 & 0.766 \\
\hline TURKISHBANK & 0.978 & 0.197 & 1 & 0.844 & 1 & 0.771 & 1 & 0.769 & 0.821 & 0.840 & 1 & 0.625 & 0.756 & 0.596 & 0.900 & 0.550 & 0.739 & 0.761 & 0.750 & 0.661 \\
\hline TBANK & 1 & 0.950 & 0.897 & 0.855 & 0.960 & 0.751 & 1 & 0.798 & 1 & 0.953 & 1 & 0.861 & 1 & 0.757 & 1 & 0.830 & 1 & 0.707 & 1 & 0.778 \\
\hline TEB & 1 & 0.865 & 1 & 0.924 & 0.832 & 0.870 & 0.900 & 0.828 & 0.952 & 0.973 & 0.977 & 0.983 & 0.954 & 0.985 & 1 & 1 & 1 & 0.941 & 1 & 0.786 \\
\hline Ziraat Bankas1 & 1 & 0.419 & 1 & 0.818 & 1 & 0.687 & 1 & 0.740 & 1 & 0.779 & 1 & 0.646 & 1 & 0.673 & 1 & 0.619 & 1 & 0.668 & 1 & 0.526 \\
\hline Garanti & 1 & 0.739 & 1 & 0.927 & 1 & 0.785 & 1 & 1 & 1 & 1 & 1 & 0.801 & 1 & 0.728 & 1 & 0.788 & 1 & 0.843 & 0.999 & 0.689 \\
\hline HALKBANK & 1 & 0.694 & 1 & 0.881 & 1 & 0.794 & 1 & 0.775 & 1 & 0.857 & 1 & 0.711 & 1 & 0.698 & 1 & 0.743 & 1 & 0.768 & 1 & 0.648 \\
\hline Türkiye İş Bankası & 1 & 0.618 & 1 & 0.735 & 1 & 0.592 & 1 & 0.697 & 1 & 0.810 & 1 & 0.697 & 1 & 0.689 & 1 & 0.712 & 1 & 0.726 & 1 & 0.670 \\
\hline VakıfBank & 1 & 0.616 & 1 & 0.738 & 1 & 0.699 & 1 & 0.789 & 1 & 0.849 & 1 & 0.785 & 0.940 & 0.708 & 1 & 0.737 & 1 & 0.849 & 1 & 0.704 \\
\hline YapıKredi & 1 & 0.827 & 1 & 0.857 & 0.979 & 0.728 & 1 & 0.854 & 1 & 1 & 1 & 0.870 & 1 & 0.897 & 1 & 0.976 & 1 & 0.968 & 1 & 0.734 \\
\hline
\end{tabular}


Table: 4

TE and AE Scores of 23 DMU According to the BCC Method

\begin{tabular}{|c|c|c|c|c|c|c|c|c|c|c|c|c|c|c|c|c|c|c|c|c|}
\hline Company & $\mathrm{TE}_{03}$ & $\mathrm{AE}_{03}$ & $\mathrm{TE}_{04}$ & $\mathrm{AE}_{04}$ & $\mathrm{TE}_{05}$ & $\mathrm{AE}_{05}$ & $\mathrm{TE}_{06}$ & $\mathrm{aE} 306$ & $\mathrm{TE}_{07}$ & $\mathrm{AE}_{07}$ & $\mathrm{TE}_{08}$ & $\mathrm{AE}_{08}$ & $\mathrm{TE}_{09}$ & $\mathrm{AE}_{09}$ & $\mathrm{TE}_{10}$ & $\mathrm{AE}_{10}$ & $\mathrm{TE}_{11}$ & $\mathrm{AE}_{11}$ & $\mathrm{TE}_{12}$ & $\mathrm{AE}_{12}$ \\
\hline AKBANK & 1 & 1 & 1 & 1 & 1 & 1 & 1 & 1 & 1 & 0.880 & 1 & 1 & 1 & 0.968 & 1 & 0.973 & 1 & 0.907 & 1 & 1 \\
\hline ABank & 1 & 0.834 & 1 & 1 & 1 & 1 & 1 & 1 & 1 & 1 & 1 & 0.901 & 1 & 1 & 1 & 1 & 1 & 0.836 & 1 & 0.834 \\
\hline Anadolubank & 1 & 0.668 & 1 & 0.696 & 0.864 & 0.795 & 0.864 & 0.795 & 1 & 0.970 & 1 & 0.860 & 1 & 0.821 & 1 & 0.870 & 0.981 & 0.861 & 0.950 & 0.819 \\
\hline A\&T Bank & 1 & 1 & 1 & 1 & 1 & 1 & 1 & 1 & 1 & 1 & 1 & 1 & 1 & 1 & 1 & 1 & 1 & 0.662 & 1 & 0.678 \\
\hline BURGAN BANK & 0.952 & 0.767 & 0.898 & 0.781 & 1 & 0.647 & 1 & 0.647 & 1 & 0.962 & 1 & 0.936 & 1 & 0.875 & 1 & 0.935 & 1 & 0.849 & 0.909 & 0.815 \\
\hline Citibank & 1 & 1 & 1 & 1 & 1 & 1 & 1 & 1 & 1 & 1 & 1 & 0.989 & 1 & 1 & 1 & 0.998 & 1 & 0.770 & 1 & 1 \\
\hline DenizBank & 1 & 0.693 & 1 & 0.942 & 1 & 0.939 & 1 & 0.939 & 0.986 & 0.949 & 1 & 1 & 1 & 1 & 1 & 1 & 1 & 1 & 1 & 0.854 \\
\hline Deutsche Bank & 1 & 1 & 1 & 1 & 1 & 1 & 1 & 1 & 1 & 1 & 1 & 1 & 1 & 1 & 1 & 0.492 & 1 & 1 & 1 & 1 \\
\hline Fibabanka & 1 & 0.594 & 0.656 & 0.939 & 0.927 & 0.714 & 0.927 & 0.714 & 1 & 0.661 & 1 & 0.855 & 1 & 0.816 & 0.895 & 0.878 & 1 & 0.908 & 1 & 0.866 \\
\hline FINANSBANK & 1 & 1 & 1 & 1 & 1 & 1 & 1 & 1 & 1 & 1 & 1 & 1 & 1 & 1 & 1 & 1 & 1 & 1 & 1 & 0.967 \\
\hline HSBC & 1 & 1 & 1 & 1 & 1 & 0.984 & 1 & 0.984 & 1 & 1 & 1 & 1 & 1 & 1 & 1 & 1 & 1 & 1 & 1 & 0.934 \\
\hline ING BANK & 1 & 1 & 1 & 1 & 1 & 0.836 & 1 & 0.836 & 0.944 & 0.950 & 1 & 0.946 & 1 & 1 & 1 & 1 & 1 & 1 & 1 & 1 \\
\hline SSekerbank & 1 & 1 & 1 & 1 & 1 & 1 & 1 & 1 & 1 & 1 & 1 & 1 & 1 & 0.938 & 1 & 0.853 & 1 & 0.882 & 1 & 0.999 \\
\hline TEKSTILBANK & 1 & 0.905 & 1 & 0.966 & 1 & 0.942 & 1 & 0.942 & 1 & 1 & 1 & 1 & 0.989 & 0.942 & 1 & 0.793 & 0.988 & 0.792 & 0.988 & 0.771 \\
\hline TURKISHBANK & 1 & 0.200 & 1 & 0.715 & 1 & 0.777 & 1 & 0.777 & 0.821 & 0.840 & 1 & 0.626 & 0.772 & 0.606 & 0.952 & 0.577 & 0.749 & 0.759 & 0.777 & 0.689 \\
\hline TBANK & 1 & 1 & 1 & 0.887 & 1 & 0.792 & 1 & 0.792 & 1 & 0.953 & 1 & 0.890 & 1 & 0.796 & 1 & 0.830 & 1 & 0.728 & 1 & 0.790 \\
\hline TEB & 1 & 0.943 & 1 & 0.972 & 0.842 & 0.860 & 0.842 & 0.860 & 0.952 & 0.973 & 1 & 1 & 1 & 1 & 1 & 1 & 1 & 0.977 & 1 & 0.787 \\
\hline Ziraat Bankası & 1 & 1 & 1 & 1 & 1 & 1 & 1 & 1 & 1 & 0.779 & 1 & 1 & 1 & 1 & 1 & 1 & 1 & 1 & 1 & 1 \\
\hline Garanti & 1 & 0.962 & 1 & 1 & 1 & 1 & 1 & 1 & 1 & 1 & 1 & 1 & 1 & 1 & 1 & 1 & 1 & 1 & 1 & 1 \\
\hline HALKBANK & 1 & 1 & 1 & 1 & 1 & 1 & 1 & 1 & 1 & 0.857 & 1 & 0.969 & 1 & 0.966 & 1 & 0.991 & 1 & 0.955 & 1 & 0.677 \\
\hline Türkiye İs Bankası & 1 & 1 & 1 & 1 & 1 & 1 & 1 & 1 & 1 & 0.810 & 1 & 1 & 1 & 1 & 1 & 1 & 1 & 1 & 1 & 1 \\
\hline VakıfBank & 1 & 0.844 & 1 & 1 & 1 & 0.939 & 1 & 0.939 & 1 & 0.849 & 1 & 0.985 & 1 & 0.916 & 1 & 0.981 & 1 & 1 & 1 & 0.908 \\
\hline YapıKredi & 1 & 1 & 1 & 1 & 1 & 1 & 1 & 1 & 1 & 1 & 1 & 1 & 1 & 1 & 1 & 1 & 1 & 1 & 1 & 0.931 \\
\hline
\end{tabular}


Table 4 presents the estimations of the same efficiency values according to BCC model. In 2003, only one bank did not have TE and ten banks did not have AE. After ten years the number of the banks without TE rose to 4 while the number of the banks without AE rose to 16 . Therefore $17 \%$ of the banks did not have TE and $69 \%$ did not have AE in 2012.

The efficiency of the banks appears to be higher according to BCC model and 2008 is an efficient year for the banks. In this model, we find that the small scale banks are less efficient. According to CCR model TURKISHBANK is the least efficient bank. Fibabanka, TBANK, BURGAN BANK and TEKSTILBANK are also among the banks with lowest efficiency. The AE score of TURKISHBANK in 2003 was only $20 \%$. The efficiency of the banks decreased in number in the CCR model however, the efficiency scores in the BCC model increased.

\subsection{Window Productivity Analysis}

The window size used in this study is compatible with the methodology of Tulkens and Eeckaut (1995). The first window includes the years 2003, 2004, 2005 and 2006. When a new window is constructed, the earliest period is dropped and a new period is added. In window two, for example, the year 2003 will be dropped and the year 2007 will be added to the window. This is run for the entire time period until window 7 analyses years 2009, 2010, 2011 and 2012. Since DEA window analysis treats a DMU as different entity in each year, in a four-year window width 23 DMUs is equivalent to 92 DMUs. Subsequently, 7 four-year window widths would considerably increase the number of observations of the sample to 644 , providing a greater degree of freedom.

By using DEA window analysis in a dynamic process, efficiency of 23 banks for is evaluated for a ten-year period. In each window, an efficiency value for a bank is considered as efficiency score of a different decision unit for each year. Each window contains efficiency values for four years. The window is shifted one yearly period and the analysis is performed on the next four year set, dropping the original year and adding a new year, so the window constitutes of seven lines. In Table A1 of appendix, for example, the period 2004-2007 follows the first period of 2003-2006 for AKBANK.

There are $4 \times 23=92$ DMU in each window which gives a higher degree of freedom. All values in the first line are, for example, 1 for AKBANK. Only in the fourth line the value is 0.9957 . When the year 2003 is deducted and the year 2007 is added, we get $4 \times 23=92$ DMU again for the second window. Looking at whole seven windows, we are able to observe efficiency trend of each bank. We can see that values for a year listed one under another seem close to each other. While the value in the third line for AKBANK in 2005 is 0.975 , the values in the two lines above are " 1 ". In other words, differences of those three efficiency values for the same year are less than 5\%. Looking at Table A1, it is apparent that 
Fibabanka is the only exception. While the starting score of Fibabanka is 0.497 , the change in the course of time exceeds $10 \%$. That is a sign of instability. However, Fibabanka has the lowest average efficiency score among all banks. The column "mean" gives average efficiency values for all banks. It is seen that average efficiency score for Fibabanka is 0.866 . The inefficiency of Fibabanka is related to standard errors that occur in the window analysis table. TURKISHBANK and Fibabanka have the highest standard deviation among all banks in Table A1. The result complies with the rule specified by Charnes, et al. (1985). The lower the efficiency of DMU is, the higher the standard error is. It is also seen that standard errors of high performance banks is zero or around zero.

Efficiency values of Fibabanka for the year 2005 are $0.834,0.761$ and 0.663 . The deviation is above $20 \%$ for that year. The results are compatible with TURKISHBANK, which has the second lowest efficiency score. Efficiency score of this bank is 0.758 which is the second lowest efficiency score. Difference in efficiency values of TURKISHBANK is around $10 \%$ for the year 2006. Similarly, there is partial instability and low efficiency in this bank.

Fig. 1

Trend of Average Efficiency Scores of Banks in Window Analysis

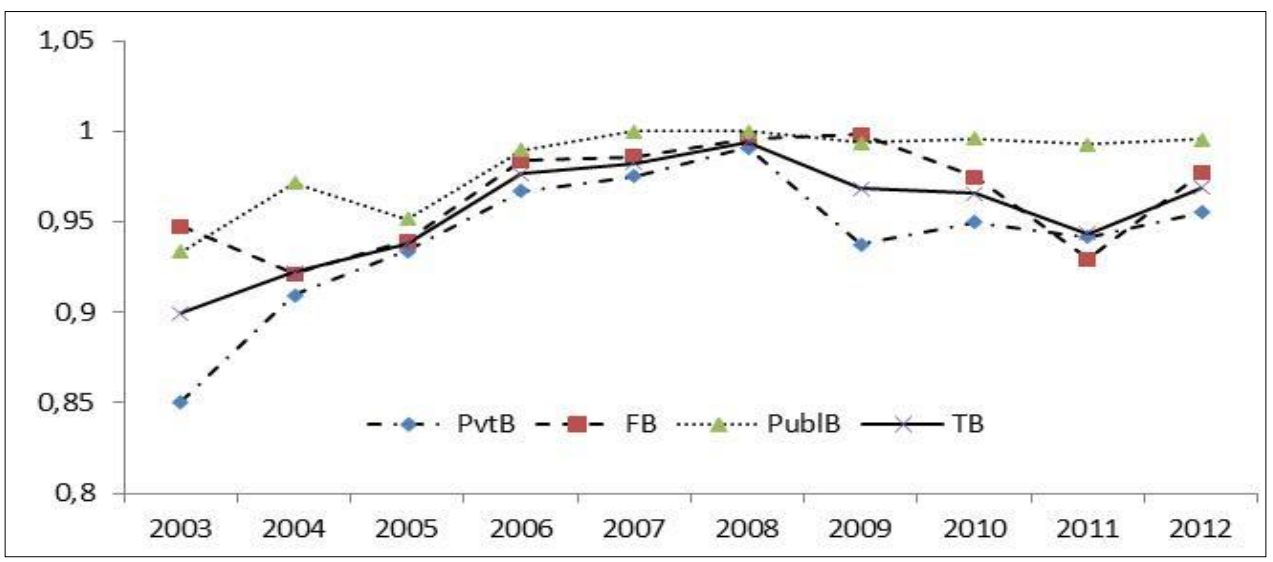

Based on the results in the Window table, the annual average of TE scores for the relevant period are given for private banks (PvtB), foreign banks (FB), public banks (PublB), and all banks (TB) in Figure 1. The table indicates that banks peak in terms of efficiency scores in the period 2006-2008. The efficiency scores of the banks vary between 0.85-0.95 in the beginning however the efficiency scores reached values between 0.95 and 1 at the end of the period. As mentioned before, public banks with high deposit have higher average efficiency scores compared to other banks. Private banks have the lowest efficiency scores. The relevant scores represent average values. However some banks among the private ones 
such as AKBANK, ABank, Türkiye iş Bankası, and Garanti have relatively higher efficiency scores. Figure 1 indicates that all banks in Turkey started off with lower efficiency scores; subsequently a reduction occurred in these scores. However, public banks sustained efficiency levels until the end of the period. The average efficiency score of public banks may result from the new regulations imposed in banking sector following the crisis in 2001.

Fig. 2

\section{Structure of Average Efficiency Scores of All Banks}

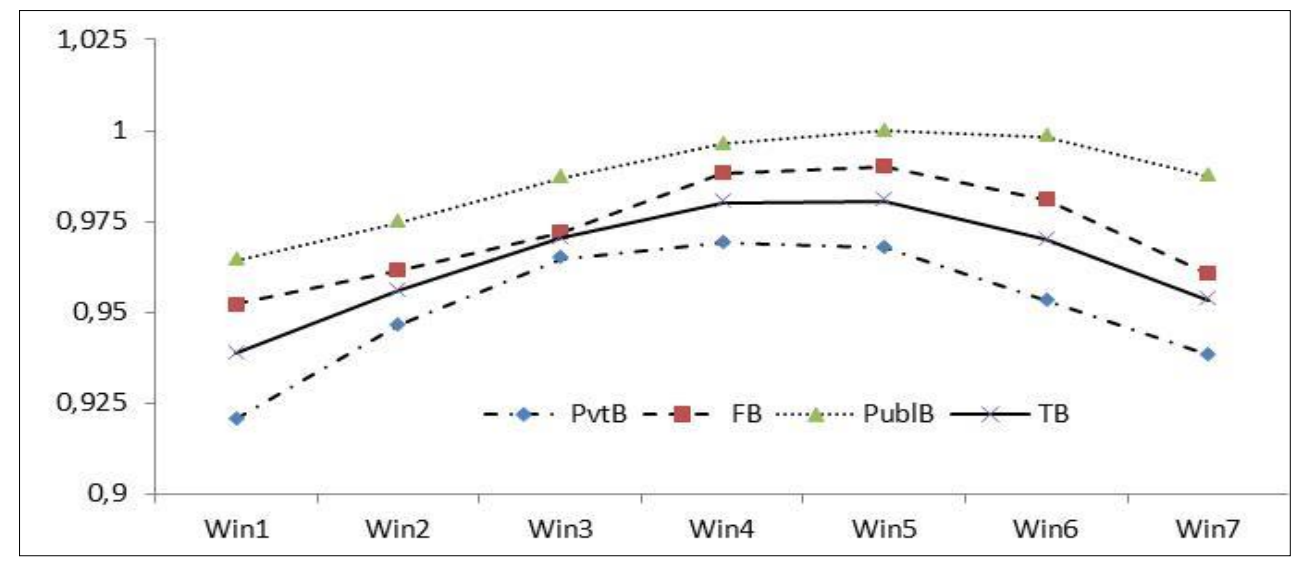

Figure 2 shows the window average for PvtB, FB, PublB, and TB. The first window (Win1) is the period of 2003-2006 and Win7 is the period of 2009-2012. Starting around $0.93-0.94$, the score exceeded 0.98 in the range of win4-win5 and went down to 0.95 in win7. The banks that have the highest efficiency score in the range of Win4-Win5 experience decline in the range of 2006-2010. In other words, the efficiency of the banks increased after 2006 and started to go down after 2010. Actually, this efficiency increase corresponds to the 2007-2008 period. We should bear in mind that Turkish economy experienced some positive macroeconomic developments in this period. The economy grew by $6.9 \%$ in 2006 ; however the growth rate declined to $4.7 \%$ in 2009 as a result of the financial crisis in 2008 and 2009.

First seven columns in Table 5 give periodical efficiency scores in the windows of each bank and the last column represents average scores. Efficiency scores in the beginning and at end of the period vary between 0.94-0.95 which suggests that the banks operating in Turkey had a stabilized structure in the given period. The last column of the table gives efficiency average of each bank. According to last column A\&T Bank, AKBANK, ABank, and Ziraat Bank are the first three banks with highest efficiency scores. Efficiency scores of the banks vary between 0.998 and 1. It is noteworthy that one of these banks is a public bank (the biggest one among all banks), two of them are private banks and 
the last one is a foreign bank with a low volume. Fibabanka is the least efficient bank with an average efficiency score of 0.866 . The average efficiency scores suggest that all banks have stable efficiency scores.

Table: 5

Window Scores of Efficiency

\begin{tabular}{|c|c|c|c|c|c|c|c|c|}
\hline Company & 2003-'06 & 2004-'07 & \begin{tabular}{|l|l|} 
2005-‘08 \\
\end{tabular} & 2006-'09 & 2007-'10 & 2008-'11 & 2009-'12 & Mean \\
\hline AKBANK & 1 & 1 & 1 & 0.999 & 1 & 1 & 1 & 1 \\
\hline ABank & 1 & 1 & 0.994 & 0.994 & 0.996 & 0.999 & 1 & 0.998 \\
\hline Anadolubank & 0.850 & 0.880 & 0.898 & 0.940 & 0.972 & 0.943 & 0.926 & 0.915 \\
\hline A\&T Bank & 1 & 1 & 1 & 1 & 1 & 1 & 1 & 1 \\
\hline BURGAN BANK & 0.872 & 0.896 & 0.936 & 1 & 0.974 & 0.946 & 0.907 & 0.933 \\
\hline Citibank & 0.990 & 1 & 0.989 & 0.975 & 0.987 & 0.914 & 0.905 & 0.966 \\
\hline DenizBank & 0.872 & 0.914 & 0.942 & 0.970 & 0.983 & 1 & 0.999 & 0.954 \\
\hline Deutsche Bank & 1 & 1 & 1 & 1 & 1 & 1 & 0.981 & 0.997 \\
\hline Fibabanka & 0.711 & 0.816 & 0.909 & 0.966 & 0.895 & 0.866 & 0.901 & 0.866 \\
\hline FINANSBANK & 0.987 & 0.987 & 1 & 1 & 0.990 & 0.973 & 0.936 & 0.982 \\
\hline HSBC & 1 & 1 & 1 & 1 & 0.998 & 0.997 & 0.934 & 0.990 \\
\hline ING BANK & 0.946 & 0.952 & 0.947 & 0.966 & 0.979 & 1 & 1 & 0.970 \\
\hline Şekerbank & 0.977 & 1 & 1 & 0.994 & 0.968 & 0.947 & 0.911 & 0.971 \\
\hline TEKSTILLBANK & 0.913 & 0.950 & 1 & 0.990 & 0.981 & 0.961 & 0.943 & 0.963 \\
\hline TURKISHBANK & 0.962 & 0.931 & 0.960 & 0.895 & 0.882 & 0.803 & 0.714 & 0.878 \\
\hline TBANK & 0.903 & 0.905 & 0.935 & 0.985 & 1 & 1 & 0.984 & 0.959 \\
\hline TEB & 0.832 & 0.860 & 0.860 & 0.901 & 0.949 & 0.974 & 0.961 & 0.905 \\
\hline Ziraat Bankas1 & 1 & 1 & 1 & 1 & 1 & 0.995 & 0.991 & 0.998 \\
\hline Garanti & 0.951 & 0.998 & 1 & 1 & 1 & 0.995 & 0.986 & 0.990 \\
\hline HALKBANK & 0.969 & 0.972 & 0.986 & 1 & 1 & 1 & 1 & 0.990 \\
\hline Türkiye İș Bankası & 0.947 & 0.993 & 1 & 1 & 1 & 0.998 & 0.994 & 0.991 \\
\hline VakıfBank & 0.924 & 0.952 & 0.975 & 0.989 & 1 & 1 & 0.972 & 0.973 \\
\hline YapıKredi & 0.983 & 0.982 & 0.991 & 0.982 & 1 & 1 & 0.983 & 0.989 \\
\hline Mean & 0.939 & 0.956 & 0.971 & 0.980 & 0.981 & 0.970 & 0.953 & \\
\hline
\end{tabular}

Table: 6

Annual Scores of Efficiency

\begin{tabular}{|c|c|c|c|c|c|c|c|c|c|c|c|}
\hline Company & 2003 & 2004 & 2005 & 2006 & 2007 & 2008 & 2009 & 2010 & 2011 & 2012 & Mean \\
\hline AKBANK & 1 & 1 & 1 & 0.999 & 1 & 1 & 1 & 1 & 1 & 1 & 1 \\
\hline ABank & 1 & 1 & 0.992 & 1 & 1 & 0.989 & 1 & 1 & 1 & 1 & 0.998 \\
\hline Anadolubank & 0.759 & 0.895 & 0.803 & 0.857 & 0.983 & 0.983 & 0.957 & 0.942 & 0.903 & 0.924 & 0.901 \\
\hline A\&T Bank & 1 & 1 & 1 & 1 & 1 & 1 & 1 & 1 & 1 & 1 & 1 \\
\hline BURGAN BANK & 0.883 & 0.788 & 0.786 & 1 & 1 & 1 & 1 & 0.900 & 0.861 & 0.885 & 0.910 \\
\hline Citibank & 1 & 0.980 & 1 & 0.974 & 1 & 0.969 & 1 & 0.991 & 0.665 & 1 & 0.958 \\
\hline DenizBank & 0.780 & 0.843 & 0.911 & 0.936 & 0.945 & 1 & 1 & 1 & 0.998 & 1 & 0.941 \\
\hline Deutsche Bank & 1 & 1 & 1 & 1 & 1 & 1 & 1 & 0.974 & 1 & 1 & 0.997 \\
\hline Fibabanka & 0.497 & 0.509 & 0.753 & 0.985 & 0.969 & 0.957 & 0.838 & 0.828 & 1 & 1 & 0.834 \\
\hline FINANSBANK & 1 & 0.947 & 1 & 1 & 1 & 1 & 0.991 & 0.944 & 0.919 & 0.962 & 0.976 \\
\hline HSBC & 1 & 1 & 1 & 1 & 1 & 1 & 0.997 & 0.964 & 0.945 & 0.947 & 0.985 \\
\hline ING BANK & 0.911 & 0.942 & 0.924 & 0.974 & 0.930 & 0.994 & 1 & 1 & 1 & 1 & 0.967 \\
\hline Şekerbank & 0.940 & 1 & 0.989 & 1 & 1 & 1 & 0.973 & 0.888 & 0.869 & 0.987 & 0.965 \\
\hline TEKSTİLBANK & 0.826 & 0.813 & 1 & 1 & 1 & 1 & 0.934 & 0.973 & 0.954 & 0.938 & 0.944 \\
\hline TURKISHBANK & 0.916 & 1 & 0.933 & 1 & 0.876 & 1 & 0.709 & 0.858 & 0.643 & 0.679 & 0.861 \\
\hline TBANK & 0.955 & 0.789 & 0.833 & 0.970 & 1 & 1 & 0.996 & 1 & 0.976 & 1 & 0.952 \\
\hline TEB & 0.790 & 0.879 & 0.818 & 0.815 & 0.897 & 0.973 & 0.917 & 0.985 & 0.992 & 1 & 0.907 \\
\hline Ziraat Bankası & 1 & 1 & 1 & 1 & 1 & 1 & 1 & 1 & 0.978 & 0.986 & 0.996 \\
\hline Garanti & 0.816 & 0.990 & 1 & 1 & 1 & 1 & 1 & 0.975 & 1 & 0.999 & 0.978 \\
\hline HALKBANK & 1 & 1 & 0.903 & 1 & 1 & 1 & 1 & 1 & 1 & 1 & 0.990 \\
\hline Türkiye İş Bankası & 0.817 & 0.973 & 1 & 1 & 1 & 1 & 1 & 1 & 0.996 & 0.978 & 0.976 \\
\hline VakıfBank & 0.801 & 0.915 & 0.952 & 0.968 & 1 & 1 & 0.981 & 0.987 & 1 & 1 & 0.961 \\
\hline Yap1Kredi & 0.998 & 0.943 & 0.984 & 0.979 & 1 & 1 & 0.983 & 1 & 1 & 1 & 0.989 \\
\hline Mean & 0.900 & 0.922 & 0.938 & 0.976 & 0.983 & 0.994 & 0.969 & 0.966 & 0.944 & 0.969 & \\
\hline
\end{tabular}


Table 6 gives efficiency score by year and periodical average of the banks. Efficiency averages of the banks indicate that A\&T Bank, AKBANK and A Bank are the first three banks with highest efficiency scores followed by Ziraat Bank. AKBANK ranks the fourth in the previous table that represents estimated periodical results however it replaces Ziraat Bank in this table. Scores of the respective banks vary between 1-0.99. These banks sustained high efficiency scores throughout the period. Furthermore, Fibabanka exhibits the lowest performance within the given period. Fibabanka had a score of 0.497 in the beginning of the period; however its efficiency score changed ultimately in the end. Despite its performance Fibabanka has the lowest performance among all banks. Finally, all the banks exhibited constant and increasing trend for the period.

Despite the increasing trend in general, the efficiency score declined in the period 2008-2009 and continued to decline until 2012. The decline in efficiency scores can be related to the financial crisis in 2008 and 2009. We observe that the banks have not managed to recover from the effects of the financial crisis even until 2012.

Finally, the banks are evaluated in terms of stable efficiency. In Table 7, the last column gives the biggest difference between the windows of DMUs. The fifth column indicates the highest difference of each DMU given in the Window table for the same year. The fourth column shows standard deviations of the average efficiency scores. As seen in the table these two variables are high for the banks with the lowest efficiency scores. Fibabanka and TURKISHBANK have the lowest average of efficiency score. The window difference value of Fibabanka is $50 \%$ and that of TURKISHBANK is $37 \%$.

Table: 7

\section{Average by Term}

\begin{tabular}{|c|c|c|c|c|c|}
\hline DMU & Year Average & Window Average & Standard Deviation & Year Difference & Window Difference \\
\hline AKBANK & 0.9999 & 0.9998 & 0.0004 & 0.0043 & 0.0043 \\
\hline ABank & 0.9980 & 0.9975 & 0.0027 & 0.0254 & 0.0254 \\
\hline Anadolubank & 0.9005 & 0.9154 & 0.0389 & 0.0811 & 0.2346 \\
\hline A\&T Bank & 1 & 1 & 0 & 0 & 0 \\
\hline BURGAN BANK & 0.9102 & 0.9329 & 0.0416 & 0.0640 & 0.2551 \\
\hline Citibank & 0.9580 & 0.9656 & 0.0363 & 0.0932 & 0.3812 \\
\hline DenizBank & 0.9413 & 0.9543 & 0.0442 & 0.0292 & 0.2197 \\
\hline Deutsche Bank & 0.9974 & 0.9972 & 0.0068 & 0.0777 & 0.0777 \\
\hline Fibabanka & 0.8337 & 0.8662 & 0.0759 & 0.1701 & 0.5027 \\
\hline FINANSBANK & 0.9763 & 0.9818 & 0.0205 & 0.0664 & 0.1141 \\
\hline HSBC & 0.9852 & 0.9898 & 0.0230 & 0.1099 & 0.1099 \\
\hline ING BANK & 0.9674 & 0.9699 & 0.0219 & 0.0922 & 0.1082 \\
\hline Șekerbank & 0.9646 & 0.9709 & 0.0301 & 0.0858 & 0.1737 \\
\hline TEKSTİLBANK & 0.9438 & 0.9625 & 0.0280 & 0.0403 & 0.2005 \\
\hline TURKISHBANK & 0.8612 & 0.8782 & 0.0843 & 0.0946 & 0.3701 \\
\hline TBANK & 0.9519 & 0.9588 & 0.0401 & 0.0680 & 0.2121 \\
\hline TEB & 0.9066 & 0.9053 & 0.0525 & 0.0646 & 0.2176 \\
\hline Ziraat Bankası & 0.9964 & 0.9979 & 0.0035 & 0.0044 & 0.0240 \\
\hline Garanti & 0.9780 & 0.9900 & 0.0166 & 0.0559 & 0.1841 \\
\hline HALKBANK & 0.9903 & 0.9896 & 0.0129 & 0.0664 & 0.1239 \\
\hline Türkiye İș Bankası & 0.9764 & 0.9905 & 0.0178 & 0.0073 & 0.1833 \\
\hline VakıfBank & 0.9605 & 0.9731 & 0.0255 & 0.0759 & 0.1992 \\
\hline Yap1Kredi & 0.9887 & 0.9887 & 0.0077 & 0.0728 & 0.0728 \\
\hline
\end{tabular}


According to Figure 3 Year difference, Window Difference and Standard Deviation value increase and decline in parallel with each other. Window Difference value is quite high compared to other values. One of the peak window differences belongs to Citibank which is an exception. Even though the average efficiency score of Citibank is high; the Window difference, Year difference and Standard deviation of Citibank are high like those of Fibabanka and TURKISHBANK which have low average of efficiency score.

Fig. 3

\section{Structure of Average Efficiency Scores of All Banks}

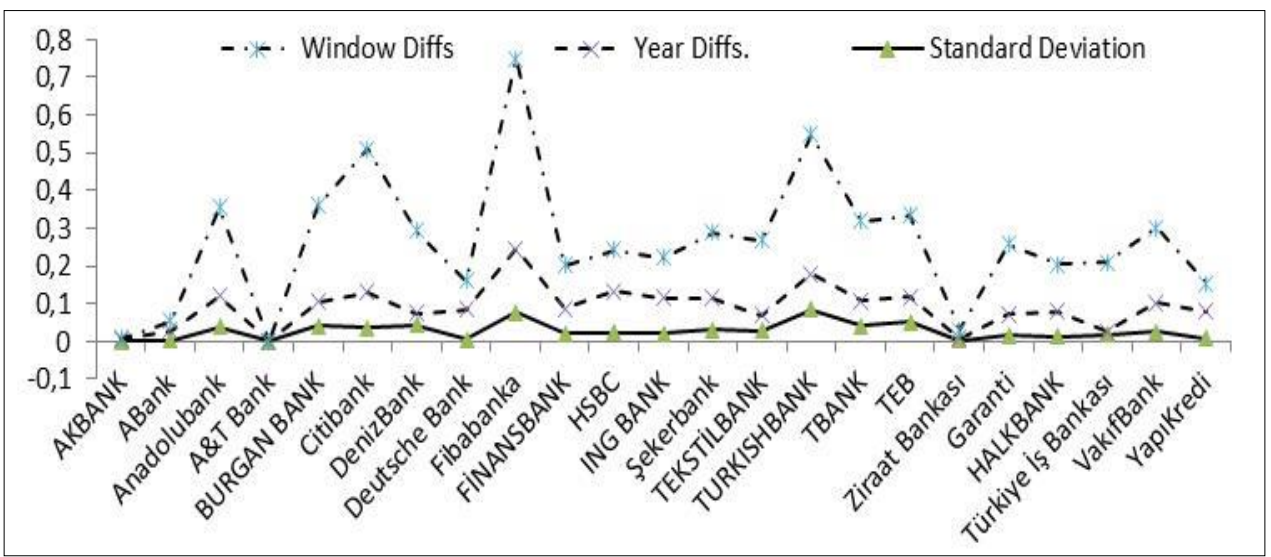

\subsection{Total Factor Productivity Analysis with Malmquist Index}

Productivity scores and parameter estimations of the banks are obtained separately in terms of TFP Analysis with an output-oriented MI. In this analysis values for TFP Change (tfpch), Technical Change (tch), Efficiency Change (ech), Pure Efficiency Change (pech), and Scale Efficiency Change (sech) of those banks are estimated.

Table 8 represents the results of constant returns and input-oriented TFP model by using MI. In the first five years and mainly in 2004 and 2005, TFP is below one. The lowest productivity is in 2011 with a decrease by $15 \%$. The highest productivity is in 2006 with an increase by $11.5 \%$. When we take the mean values of the whole period into account the TE change, the pure efficiency change and the change in the TFP are below one. This leads to the conclusion that the productivity change in the period exhibits a decreasing trend. The TFP decreases by $0.5 \%$. The relevant figures suggest that banks did not incur much loss. 
Table: 8

Malmquist Index: Annual Average Efficiency

\begin{tabular}{c|c|c|c|c|c}
\hline Year & ech & tch & pech & sech & tfpch \\
\hline 2004 & 0.997 & 0.874 & 0.980 & 0.980 & 0.871 \\
2005 & 1.017 & 0.980 & 1.006 & 1.006 & 0.997 \\
2006 & 1.015 & 1.098 & 1.011 & 1.011 & 1.115 \\
2007 & 0.995 & 0.966 & 1.003 & 1.003 & 0.961 \\
2008 & 1.012 & 1.014 & 1.002 & 1.002 & 1.026 \\
2009 & 0.983 & 1.014 & 0.989 & 0.989 & 0.997 \\
2010 & 1.008 & 1.077 & 1.005 & 1.005 & 1.086 \\
2011 & 0.989 & 0.860 & 0.993 & 0.993 & 0.851 \\
2012 & 1.000 & 1.086 & 0.996 & 0.996 & 1.087 \\
\hline Mean & 1.002 & 0.993 & 0.998 & 1.004 & 0.995 \\
\hline
\end{tabular}

Table 9 represents TFP and other efficiency changes of the relevant banks according to MI. When the efficiency of the entire period for all the banks is taken into account, we see that pech value decreases by $0.2 \%$ whereas $t c h$ value does not change at all. The ech and $t f p c h$ values increase by $0.2 \%$ and sech value increases by $0.4 \%$. There are 6 banks $t f p c h$ of which is below one. In terms of mean efficiency of all the enterprises, all values except for pech increase by thousandth.

Table: 9

Malmquist Index: Firms’ Average Efficiency

\begin{tabular}{rrr|c|c|c|c}
\hline Company & ech & tch & pech & sech & tfpch \\
\hline AKBANK & 1.000 & 1.022 & 1.000 & 1.000 & 1.022 \\
ABank & 1.000 & 1.010 & 1.000 & 1.000 & 1.010 \\
Anadolubank & 0.993 & 1.057 & 0.994 & 0.999 & 1.049 \\
A\&T Bank & 1.000 & 0.984 & 1.000 & 1.000 & 0.984 \\
BURGAN BANK & 0.998 & 1.005 & 0.995 & 1.003 & 1.003 \\
Citibank & 1.000 & 1.030 & 1.000 & 1.000 & 1.030 \\
DenizBank & 1.000 & 1.031 & 1.000 & 1.000 & 1.031 \\
Deutsche Bank & 1.000 & 0.555 & 1.000 & 1.000 & 0.555 \\
Fibabanka & 1.081 & 1.064 & 1.000 & 1.081 & 1.150 \\
FINANSBANK & 1.000 & 1.004 & 1.000 & 1.000 & 1.004 \\
HSBC & 0.997 & 0.999 & 1.000 & 0.997 & 0.996 \\
ING BANK & 1.000 & 1.061 & 1.000 & 1.000 & 1.061 \\
Şekerbank & 1.000 & 0.993 & 1.000 & 1.000 & 0.993 \\
TEKSTILBANK & 0.997 & 1.075 & 0.999 & 0.999 & 1.072 \\
TURKISHBANK & 0.971 & 1.073 & 0.972 & 0.999 & 1.042 \\
TBANK & 1.000 & 1.067 & 1.000 & 1.000 & 1.067 \\
TEB & 1.004 & 1.005 & 1.000 & 1.004 & 1.010 \\
Ziraat Bankas1 & 1.000 & 0.977 & 1.000 & 1.000 & 0.977 \\
Garanti & 1.000 & 1.014 & 1.000 & 1.000 & 1.014 \\
HALKBANK & 1.000 & 0.984 & 1.000 & 1.000 & 0.984 \\
Türkiye İş Bankas1 & 1.006 & 1.013 & 1.000 & 1.006 & 1.020 \\
VakifBank & 1.001 & 1.045 & 1.000 & 1.001 & 1.046 \\
YapiKredi & 1.000 & 1.013 & 1.000 & 1.000 & 1.013 \\
\hline & 1.002 & 1.000 & 0.998 & 1.004 & 1.002 \\
\hline
\end{tabular}

If Malmquist and Window analysis are evaluated together, one can see the relation between the efficiency change and the efficiency levels obtained in form of moving 
averages. The following figure represents both tfpch and Window efficiency scores. Even though its efficiency score is high, tfpch of Deutsche Bank shows low performance. Other values are in parallel. As seen in Figure 4, trends of window average changes (WINDOWCH) and year average changes (YEARCH) seem to be similar however deviations in window average are stronger. Surprisingly if changes in TFP level (TFPCH) is higher, the window average lowers and year average changes. In other words, as TFP gets higher in value, deviations in window and year averages decline. Deviations of FINANSBANK and Deutsche Bank are noteworthy as well.

Fig. 4

Changes in TFP, Window Average and Year Average

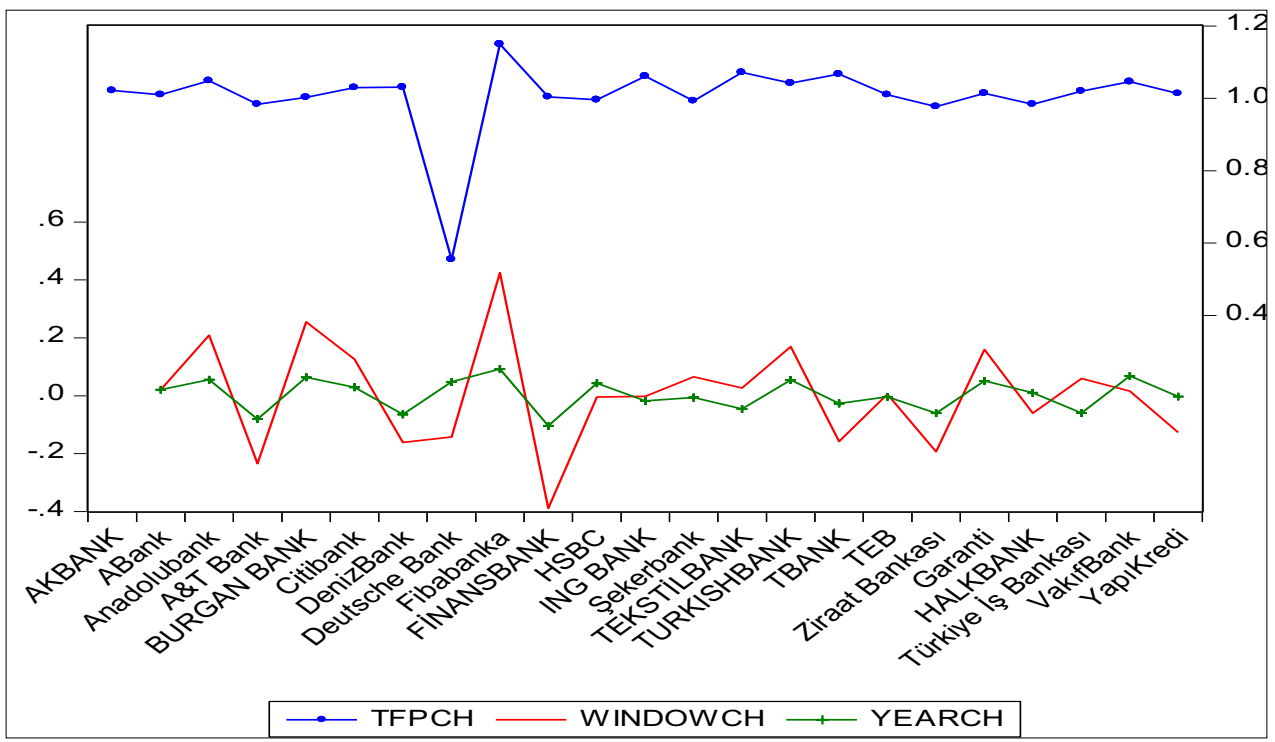

\section{Conclusion}

This study employs DEA in order to obtain technical and AE scores of 23 efficient commercial banks which operate in Turkey uninterruptedly between 2003 and 2012.

According to CCR model analysis 3 banks are not technically efficient in the first year; however the number of technically inefficient banks rose to 6 at the end of the period. In $\mathrm{AE}$ analysis 5 banks are efficient in the first year and the number of efficient banks declines to 4 in the last year. Thus, approximately $12.5-25 \%$ of the banks do not have TE and $75-80 \%$ of the banks do not have AE according to CCR model analysis. 
The results of $\mathrm{BCC}$ model analysis indicate that number of technically inefficient banks in the beginning of the period is one and it increases to 4 at the end. The number of the banks that have AE is 13 in the beginning of the study period then it decreases to 7 . Even though efficiency of the banks decreased in number, efficiency scores increased in both BCC and CCR models.

The results of the constant returns and input-oriented TFP are found using MI. The TFP in the first five years mainly in 2004 and 2005 is below one. The lowest productivity is observed in 2011 with a decrease by $15 \%$. The highest productivity is seen in 2006 with an increase by $11.5 \%$. This leads to the conclusion that productivity change in the study period exhibits a decreasing trend. The TFP decreases only by $0.5 \%$. These figures suggest that the banks did not incur much loss.

Window average efficiency scores of the banks obtained using DEA window analysis vary between 0.94-0.95 throughout the period which indicates that the banks operating in Turkey in the given period exhibits a stable structure. A\&T Bank, AKBANK and Ziraat Bank are the first three banks with the highest efficiency averages. One of them is a public bank (the largest of all) the other is private and the last one is a foreign bank. Fibabanka is the least efficient bank with an average efficiency score of 0.866 . Overall, all banks included in the study have constant efficiency scores.

Efficiency scores and periodical averages of the banks analyzed by DEA indicate that A\&T Bank, AKBANK and A Bank are the first three banks with highest efficiency scores followed by Ziraat Bank. These banks sustained high efficiency scores throughout the period. Furthermore, Fibabanka exhibits the lowest performance within the given period. Fibabanka had a score of 0.497 in the beginning of the period; however its efficiency score changed ultimately in the end. Two banks with the least efficiency are among the ones with the highest window difference and standard deviation value. We can claim that decrease in efficiency scores results from the financial crisis experienced in 2008 and 2009.

\section{References}

Asmild, M. \& J.C. Paradi \& V. Aggarwall \& C. Schaffnit (2004), “Combining DEA window analysis with the Malmquist Index approach in a study of the Canadian banking industry", Journal of Productivity Analysis, 21, 67-89.

Avkiran, N.K. (2004), "Decomposing technical efficiency and window analysis", Studies in Economics and Finance, 22 (1), 61-91.

Avkiran, N.K. (2008), "Association of DEA super-efficiency estimates with financial ratios: Investigating the case for Chinese banks", Omega, 39, 323-334.

Banker, R.D. \& A. Charnes \& W.W. Cooper (1984), "Some models for estimating technical and scale inefficiencies in data envelopment analysis", Management Science, 30(9), 10781092 . 

and Malmquist Index Analysis for the Period of 2003-2012", Sosyoekonomi, Vol. 23(24), 71-97.

Caves, D. \& L.R. Christiensen \& W.E. Diewert (1982), “The economic theory of indeks numbers and the measurement of input, output and productivity", Econometrica, 50, 1393-1414.

Charnes, A. \& W.W. Cooper \& A.Y. Lewin \& R.C. Morey \& J. Rousseau (1985), "Sensitivity and stability analysis in DEA", Annals of Operations Research, 2, 139-156.

Charnes, A. \& W.W. Cooper \& E. Rhodes (1978), "Measuring the efficiency of decision making units", European Journal of Operational Research, 2, 429-444.

Charnes, A. \& W.W. Cooper \& E. Rhodes (1979), "Short communication: Measuring the efficiency of decision making units", European Journal of Operational Research, 3, 339.

Charnes, A. \& W.W. Cooper \& L.M. Seiford (1995), "Extension to DEA models", in: A. Charnes, W.W. Cooper, A.Y. Lewin, \& L.M. Seiford (eds.), Data envelopment analysis: Theory, methodology and applications, Berlin: Springer.

Cooper, W.W. \& L.M. Seiford \& K. Tone (2006), Introduction to data envelopment analysis and its uses, New York: Springer.

Cooper, W.W. \& L.M. Seiford \& J. Zhu (2011), "Data envelopment analysis: History, models, and interpretations", in: W.W. Cooper, L.M. Seiford, \& J. Zhu (eds.), Handbook on Data Envelopment Analysis ( $2^{\text {nd }}$ Ed.), Berlin: Springer.

Coşkun, M. \& H.N. Ardor \& A.H. Çermikli \& H.O. Eruygur \& F. Öztürk \& İ. Tokatlığlu \& G. Aykaç \& T. Dağlaroğlu (2012), Türkiye'de bankacılık sektörü piyasa yapısı, firma davranışlart ve rekabet analizi, İstanbul: Türkiye Bankalar Birliği.

Das, A. \& S. Ghosh (2006), "Financial deregulation and efficiency: An empirical analysis of Indian banks during the post reform period", Review of Financial Economics, 15, 193-221.

Debreu, G. (1951), "The coefficient of resource utilization", Econometrica, 19(3), 273-292.

Denizer, C.A. \& M. Dinc \& M. Tarimcilar (2007), "Financial liberalization and banking efficiency: Evidence from Turkey", Journal of Productivity Analysis, 27, 177-195. Doi: 10.1007/s11123-007-0035-9

Farrell, M.J. (1957), "The measurement of productive efficiency", Journal of the Royal Statistical Society, 120(3), 253-281.

Fukuyama, H. \& R. Matousek (2011), "Efficiency of Turkish banking: Two-stage network system. Variable returns to scale model", Journal of International Financial Markets, Institutions \& Money, 21, 75-91. Doi: 10.1016/j.intfin.2010.08.004

Havranek, T. \& Z. Irsova (2013), "Determinants of bank performance in transition countries: A data envelopment analysis", Transition Studies Review, 20, 1-17. Doi: 10.1007/s11300-013$0270-\mathrm{x}$

Isik, I. \& M.K. Hassan (2003), "Financial deregulation and total factor productivity change: An empirical study of Turkish commercial banks", Journal of Banking \& Finance, 27, 1455-1485. Doi: 10.1016/S0378-4266(02)00288-1

Koopmans, T.C. (1951), “An analysis of production as an efficient combination of activities", in: T. C. Koopmans (ed.), Activity analysis of production and allocation, New Jersey: John Wiley and Sons.

Kutlar, A. \& A. Kabasakal \& M. Sarıkaya (2013), "Determination of the efficiency of the world railway companies by method of DEA and comparison of their efficiency by Tobit analysis", Quality and Quantity, 47(6), 3575-3602. Doi: 10.1007/s11135-012-9741-0 
Kutlar, A. \& A. Kabasakal \& A. Babacan (2015), "Dynamic Efficiency of Turkish Banks: a DEA Window and Malmquist Index Analysis for the Period of 2003-2012", Sosyoekonomi, Vol. 23(24), 71-97.

Liu, F.F. \& P.H. Wang (2008), "DEA Malmquist productivity measure: Taiwanese semiconductor companies", International Journal of Production Economic, 112, 367-379.

Malmquist S. (1953), "Indeks number and indifferences surfaces”, Trabajos de Estatistica, 4, 209242.

Mercan, M. \& A. Reisman \& R. Yolalan \& A.B. Emel (2003), "The effect of scale and mode of ownership on the financial performance of the Turkish banking sector: results of a DEAbased analysis", Socio-Economic Planning Sciences, 37, 185-202. Doi: 10.1016/S00380121(02)00045-9

Paradin, J.C. \& H. Zhu (2013), "A survey on bank branch efficiency and performance research with data envelopment analysis", Omega, 41, 61-79.

Pasiouras, F. (2008), "Estimating the technical and scale efficiency of Greek commercial banks: The impact of credit risk, off-balance sheet activities, and international operations", Research in International Business and Finance, 22, 301-318.

Staub, R.B. \& G.S. Souza \& B.M. Tabak (2010), "Innovative applications of O.R. evolution of bank efficiency in Brazil: A DEA approach”, European Journal of Operational Research, 202, 204-213.

Sufian, F. (2006), "Trends in the efficiency of publicly listed Malaysian commercial banks overtime: A non-parametric DEA window analysis approach", Banks and Bank Systems, 1(2), 144-167.

Sufian, F. \& M.Z. Abdulmajid (2007a), "Deregulation, consolidation and banks efficiency in Singapore: Evidence from event study window approach and Tobit analysis", International Review of Economics, 54, 261-283. Doi: 10.1007/s12232-007-0017-2

Sufian, F. \& M.Z. Abdulmajid (2007b), "Singapore banking efficiency and its relation to stock returns: A DEA window analysis approach", International Journal of Business Studies, 15(1), 83-106.

Tulkens, H. \& P.V. Eeckaut (1995), "Nonparametric efficiency, progress and regress measures for panel data: Methodological aspects", European Journal of Operations Research, 80, 474-499.

Unvan, Y.A. \& H. Tatlidil (2012) "Efficiency in the Turkish banking system: A data envelopment approach", International Journal of Basic \& Applied Sciences, 12(02), 168-186.

Webb, R.W. (2003), "Levels of efficiency in UK retail banks: A DEA window analysis", International Journal of the Economics of Business, 10(3), 305-322.

Yang, C. (2014), "An enhanced DEA model for decomposition of technical efficiency in banking", Annals of Operations Research, 214, 167-185. Doi: 10.1007/s10479-011-0926-Z 
Kutlar, A. \& A. Kabasakal \& A. Babacan (2015), "Dynamic Efficiency of Turkish Banks: a DEA Window and Malmquist Index Analysis for the Period of 2003-2012", Sosyoekonomi, Vol. 23(24), 71-97.

Table: A1 Window Analysis

\begin{tabular}{|c|c|c|c|c|c|c|c|c|c|c|c|c|}
\hline & 2003 & 2004 & 2005 & 2006 & 2007 & 2008 & 2009 & 2010 & 2011 & 2012 & Mean & Std Dev \\
\hline \multirow[t]{8}{*}{ AKBANK } & 1 & 1 & 1 & 1 & & & & & & & 1 & 0 \\
\hline & & 1 & 1 & 1 & 1 & & & & & & 1 & 0 \\
\hline & & & 1 & 1 & 1 & 1 & & & & & 1 & 0 \\
\hline & & & & 0.996 & 1 & 1 & 1 & & & & 0.999 & 0.002 \\
\hline & & & & & 1 & 1 & 1 & 1 & & & 1 & 0 \\
\hline & & & & & & 1 & 1 & 1 & 1 & & 1 & 0 \\
\hline & & & & & & & 1 & 1 & 1 & 1 & 1 & 0 \\
\hline & & & & & & & & & Bank & Gean & 1 & \\
\hline \multirow[t]{8}{*}{ ABank } & 1 & 1 & 1 & 1 & & . & 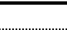 & 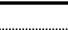 & & & 1 & 0 \\
\hline & & 1 & 1 & 1 & 1 & & & & & & 1 & 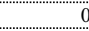 \\
\hline & & & 0.975 & 1 & 1 & 1 & & & & & 0.994 & 0.011 \\
\hline & & & & 1 & 1 & 0.975 & 1 & & & & 0.994 & 0.011 \\
\hline & & & & & 1 & 0.986 & 1 & 1 & & & 0.996 & 0.006 \\
\hline & & & & & & 0.995 & 1 & 1 & 1 & & 0.999 & 0.002 \\
\hline & & & & & & & 1 & 1 & 1 & 1 & 1 & 0 \\
\hline & & & & & & & & & Bank & Mean & 0.998 & \\
\hline \multirow[t]{8}{*}{ Anadolubank } & 0.759 & 0.907 & 0.821 & 0.911 & & & & & & & 0.850 & 0.063 \\
\hline & & 0.883 & 0.803 & 0.848 & 0.985 & & & & & & 0.880 & 0.067 \\
\hline & & & 0.784 & 0.830 & 0.985 & 0.994 & & & & & 0.898 & 0.093 \\
\hline & & & & 0.838 & 0.981 & 0.980 & 0.960 & & & & 0.940 & 0.059 \\
\hline & & & & & 0.981 & 0.980 & 0.960 & 0.969 & & & 0.972 & 0.009 \\
\hline & & & & & & 0.979 & 0.960 & 0.929 & 0.905 & & 0.943 & 0.028 \\
\hline & & & & & & & 0.951 & 0.927 & 0.901 & 0.924 & 0.926 & 0.018 \\
\hline & & & & & & & & & Bank & Mean & 0.915 & \\
\hline \multirow[t]{8}{*}{ A\&T Bank } & 1 & 1 & 1 & 1 & & & & & & & 1 & 0 \\
\hline & & 1 & 1 & 1 & 1 & & & & & & 1 & 0 \\
\hline & & & 1 & 1 & 1 & 1 & & & & & 1 & 0 \\
\hline & & & & 1 & 1 & 1 & 1 & & & & 1 & 0 \\
\hline & & & & & 1 & 1 & 1 & 1 & & & 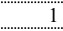 & 0 \\
\hline & & & & & & 1 & 1 & 1 & 1 & & 1 & 0 \\
\hline & & & & & & & 1 & 1 & 1 & 1 & 1 & 0 \\
\hline & & & & & & & & & Bank & Mean & 1 & \\
\hline \multirow[t]{8}{*}{ BURGAN BANK } & 0.883 & 0.796 & 0.809 & 1 & & & & & & & 0.872 & 0.081 \\
\hline & & 0.780 & 0.803 & 1 & 1 & & & & & & 0.896 & 0.105 \\
\hline & & & 0.745 & 1 & 1 & 1 & & & & & 0.936 & 0.110 \\
\hline & & & & 1 & 1 & 1 & 1 & & & & 1 & 0 \\
\hline & & & & & 1 & 1 & 1 & 0.896 & & & 0.974 & 0.045 \\
\hline & & & & & & 1 & 1 & 0.891 & 0.892 & & 0.946 & 0.054 \\
\hline & & & & & & & 1 & 0.914 & 0.831 & 0.885 & 0.907 & 0.061 \\
\hline & & & & & & & & & Bank & Mean & 0.933 & \\
\hline \multirow[t]{8}{*}{ Citibank } & 1 & 0.960 & 1 & 1 & & & & & & & 0.990 & 0.017 \\
\hline & & 1 & 1 & 1 & 1 & & & & & & 1 & 0 \\
\hline & & & 1 & 0.955 & 1 & 1 & & & & & 0.989 & 0.020 \\
\hline & & & & 0.942 & 1 & 0.959 & 1 & & & & 0.975 & 0.026 \\
\hline & & & & & 1 & 0.959 & 1 & 0.988 & & & 0.987 & 0.017 \\
\hline & & & & & & 0.958 & 1 & 0.986 & 0.712 & & 0.914 & 0.118 \\
\hline & & & & & & & 1 & 1 & 0.619 & 1 & 0.905 & 0.165 \\
\hline & & & & & & & & & Bank & Mean & 0.966 & \\
\hline \multirow[t]{8}{*}{ DenizBank } & 0.780 & 0.850 & 0.919 & 0.939 & & & & & & & 0.872 & 0.062 \\
\hline & & 0.837 & 0.919 & 0.939 & 0.962 & & & & & & 0.914 & 0.047 \\
\hline & & & 0.895 & 0.926 & 0.947 & 1 & & & & & 0.942 & 0.038 \\
\hline & & & & 0.941 & 0.940 & 1 & 1 & & & & 0.970 & 0.030 \\
\hline & & & & & 0.933 & 1 & 1 & 1 & & & 0.983 & 0.029 \\
\hline & & & & & & 1 & 1 & 1 & 1 & & 1 & 0 \\
\hline & & & & & & & 1 & 1 & 0.996 & 1 & 0.999 & 0.002 \\
\hline & & & & & & & & & Bank & Gean & 0.954 & \\
\hline \multirow[t]{5}{*}{ Deutsche Bank } & 1 & 1 & 1 & 1 & & & & & & & 1 & 0 \\
\hline & & 1 & 1 & 1 & 1 & & & & & & 1 & 0 \\
\hline & & & 1 & 1 & 1 & 1 & & & & & 1 & 0 \\
\hline & & & & 1 & 1 & 1 & 1 & & & & 1 & 0 \\
\hline & & & & & 1 & 1 & 1 & 1 & & & 1 & 0 \\
\hline
\end{tabular}


Kutlar, A. \& A. Kabasakal \& A. Babacan (2015), "Dynamic Efficiency of Turkish Banks: a DEA Window and Malmquist Index Analysis for the Period of 2003-2012", Sosyoekonomi, Vol. 23(24), 71-97.

\begin{tabular}{|c|c|c|c|c|c|c|c|c|c|c|c|c|}
\hline & 2003 & 2004 & 2005 & 2006 & 2007 & 2008 & 2009 & 2010 & 2011 & 2012 & Mean & Std Dev \\
\hline & & & & & & 1 & 1 & 1 & 1 & & 1 & 0 \\
\hline & & & & & & & 1 & 0.922 & 1 & 1 & 0.981 & 0.034 \\
\hline & & & & & & & & & Bank & Gean & 0.997 & \\
\hline \multirow[t]{8}{*}{ Fibabanka } & 0.497 & 0.514 & 0.834 & 1 & & & & & & & 0.711 & 0.214 \\
\hline & & 0.504 & 0.761 & 1 & 1 & & & & & & 0.816 & 0.205 \\
\hline & & & 0.663 & 0.972 & 1 & 1 & & & & & 0.909 & 0.142 \\
\hline & & & & 0.967 & 0.951 & 1 & 0.945 & & & & 0.966 & 0.021 \\
\hline & & & & & 0.926 & 0.957 & 0.841 & 0.855 & & & 0.895 & 0.049 \\
\hline & & & & & & 0.872 & 0.781 & 0.811 & 1 & & 0.866 & 0.084 \\
\hline & & & & & & & 0.786 & 0.820 & 1 & 1 & 0.901 & 0.099 \\
\hline & & & & & & & & & Bank & Gean & 0.866 & \\
\hline \multirow[t]{8}{*}{ FINANSBANK } & 1 & 0.948 & 1 & 1 & & & & & & & 0.987 & 0.023 \\
\hline & & 0.946 & 1 & 1 & 1 & & & & & & 0.987 & 0.023 \\
\hline & & & 1 & 1 & 1 & 1 & & & & & 1 & 0 \\
\hline & & & & 1 & 1 & 1 & 1 & & & & 1 & 0 \\
\hline & & & & & 1 & 1 & 1 & 0.960 & & & 0.990 & 0.017 \\
\hline & & & & & & 1 & 1 & 0.939 & 0.952 & & 0.973 & 0.028 \\
\hline & & & & & & & 0.965 & 0.931 & 0.886 & 0.962 & 0.936 & 0.032 \\
\hline & & & & & & & & & Bank & Mean & 0.982 & \\
\hline \multirow[t]{8}{*}{ HSBC } & 1 & 1 & 1 & 1 & & & & & & & 1 & 0 \\
\hline & & 1 & 1 & 1 & 1 & & & & & & 1 & 0 \\
\hline & & & 1 & 1 & 1 & 1 & & & & & 1 & 0 \\
\hline & & & & 1 & 1 & 1 & 1 & & & & 1 & 0 \\
\hline & & & & & 1 & 1 & 1 & 0.992 & & & 0.998 & 0.004 \\
\hline & & & & & & 1 & 1 & 0.989 & 1 & & 0.997 & 0.005 \\
\hline & & & & & & & 0.986 & 0.911 & 0.890 & 0.947 & 0.934 & 0.037 \\
\hline & & & & & & & & & Bank & Tean & 0.990 & \\
\hline \multirow[t]{8}{*}{ ING BANK } & 0.911 & 0.896 & 0.979 & 1 & & & & & & & 0.946 & 0.044 \\
\hline & & 0.988 & 0.901 & 0.982 & 0.935 & & & & & & 0.952 & 0.036 \\
\hline & & & 0.892 & 0.965 & 0.930 & 1 & & & & & 0.947 & 0.040 \\
\hline & & & & 0.950 & 0.927 & 0.985 & 1 & & & & 0.966 & 0.029 \\
\hline & & & & & 0.927 & 0.989 & 1 & 1 & & & 0.979 & 0.030 \\
\hline & & & & & & 1 & 1 & 1 & 1 & & 1 & 0 \\
\hline & & & & & & & 1 & 1 & 1 & 1 & 1 & 0 \\
\hline & & & & & & & & & Bank & lean & 0.970 & \\
\hline \multirow[t]{8}{*}{ Sekerbank } & 0.940 & 1 & 0.968 & 1 & & & & & & & 0.977 & 0.025 \\
\hline & & 1 & 0.998 & 1 & 1 & & & & & & 1 & 0.001 \\
\hline & & & 1 & 1 & 1 & 1 & & & & & 1 & 0 \\
\hline & & & & 1 & 1 & 1 & 0.975 & & & & 0.994 & 0.011 \\
\hline & & & & & 1 & 1 & 0.975 & 0.896 & & & 0.968 & 0.043 \\
\hline & & & & & & 1 & 0.975 & 0.903 & 0.912 & & 0.947 & 0.041 \\
\hline & & & & & & & 0.966 & 0.865 & 0.826 & 0.987 & 0.911 & 0.067 \\
\hline & & & & & & & & & Bank & Tean & 0.971 & \\
\hline \multirow[t]{8}{*}{ TEKSTILLBANK } & 0.826 & 0.826 & 1 & 1 & & & & & & & 0.913 & 0.087 \\
\hline & & 0.800 & 1 & 1 & 1 & & & & & & 0.950 & 0.087 \\
\hline & & & 1 & 1 & 1 & 1 & & & & & 1 & 0 \\
\hline & & & & 1 & 1 & 1 & 0.961 & & & & 0.990 & 0.017 \\
\hline & & & & & 1 & 1 & 0.924 & 1 & & & 0.981 & 0.033 \\
\hline & & & & & & 1 & 0.929 & 0.960 & 0.955 & & 0.961 & 0.025 \\
\hline & & & & & & & 0.921 & 0.960 & 0.953 & 0.938 & 0.943 & 0.015 \\
\hline & & & & & & & & & Bank & Tean & 0.963 & \\
\hline \multirow[t]{8}{*}{ TURKISHBANK } & 0.916 & 1 & 0.934 & 1 & & & & & & & 0.962 & 0.038 \\
\hline & & 1 & 0.892 & 1 & 0.832 & & & & & & 0.931 & 0.072 \\
\hline & & & 0.973 & 1 & 0.868 & 1 & & & & & 0.960 & 0.055 \\
\hline & & & & 1 & 0.875 & 1 & 0.706 & & & & 0.895 & 0.121 \\
\hline & & & & & 0.927 & 1 & 0.705 & 0.896 & & & 0.882 & 0.109 \\
\hline & & & & & & 1 & 0.707 & 0.848 & 0.655 & & 0.803 & 0.134 \\
\hline & & & & & & & 0.718 & 0.829 & 0.630 & 0.679 & 0.714 & 0.073 \\
\hline & & & & & & & & & Bank & Gean & 0.878 & \\
\hline \multirow[t]{6}{*}{ TBANK } & 0.955 & 0.791 & 0.866 & 1 & & & & & & & 0.903 & 0.081 \\
\hline & & 0.788 & 0.834 & 1 & 1 & & & & & & 0.905 & 0.096 \\
\hline & & & 0.798 & 0.940 & 1 & 1 & & & & & 0.935 & 0.083 \\
\hline & & & & 0.940 & 1 & 1 & 1 & & & & 0.985 & 0.026 \\
\hline & & & & & 1 & 1 & 1 & 1 & & & 1 & 0 \\
\hline & & & & & & 1 & 1 & 1 & 1 & & 1 & 0 \\
\hline
\end{tabular}


Kutlar, A. \& A. Kabasakal \& A. Babacan (2015), "Dynamic Efficiency of Turkish Banks: a DEA Window and Malmquist Index Analysis for the Period of 2003-2012", Sosyoekonomi, Vol. 23(24), 71-97.

\begin{tabular}{|c|c|c|c|c|c|c|c|c|c|c|c|c|}
\hline & 2003 & 2004 & 2005 & 2006 & 2007 & 2008 & 2009 & 2010 & 2011 & 2012 & Mean & Std Dev \\
\hline & & & & & & & 0.983 & 1 & 0.952 & 1 & 0.984 & 0.020 \\
\hline & & & & & & & & & Bank & Mean & 0.959 & \\
\hline \multirow[t]{8}{*}{ TEB } & 0.790 & 0.867 & 0.823 & 0.847 & & & & & & & 0.832 & 0.029 \\
\hline & & 0.891 & 0.820 & 0.826 & 0.902 & & & & & & 0.860 & 0.037 \\
\hline & & & 0.810 & 0.782 & 0.884 & 0.965 & & & & & 0.860 & 0.071 \\
\hline & & & & 0.807 & 0.900 & 0.977 & 0.921 & & & & 0.901 & 0.061 \\
\hline & & & & & 0.900 & 0.977 & 0.921 & 1 & & & 0.949 & 0.041 \\
\hline & & & & & & 0.975 & 0.923 & 1 & 1 & & 0.974 & 0.032 \\
\hline & & & & & & & 0.905 & 0.955 & 0.984 & 1 & 0.961 & 0.036 \\
\hline & & & & & & & & & Bank & Gean & 0.905 & \\
\hline \multirow[t]{8}{*}{ Ziraat Bankas1 } & 1 & 1 & 1 & 1 & & & & & & & 1 & 0 \\
\hline & & 1 & 1 & 1 & 1 & & & & & & 1 & 0 \\
\hline & & & 1 & 1 & 1 & 1 & & & & & 1 & 0 \\
\hline & & & & 1 & 1 & 1 & 1 & & & & 1 & 0 \\
\hline & & & & & 1 & 1 & 1 & 1 & & & 1 & 0 \\
\hline & & & & & & 1 & 1 & 1 & 0.980 & & 0.995 & 0.009 \\
\hline & & & & & & & 1 & 1 & 0.976 & 0.986 & 0.991 & 0.010 \\
\hline & & & & & & & & & Bank & Gean & 0.998 & \\
\hline \multirow[t]{8}{*}{ Garanti } & 0.816 & 0.989 & 1 & 1 & & 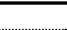 & & 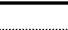 & & & 0.951 & 0.078 \\
\hline & & 0.992 & 1 & 1 & 1 & & & & & & 0.998 & 0.003 \\
\hline & & & 1 & 1 & 1 & 1 & & & & & 1 & 0 \\
\hline & & & & 1 & 1 & 1 & 1 & & & & 1 & 0 \\
\hline & & & & & 1 & 1 & 1 & 1 & & & 1 & 0 \\
\hline & & & & & & 1 & 1 & 0.979 & 1 & & 0.995 & 0.009 \\
\hline & & & & & & & 1 & 0.944 & 1 & 0.999 & 0.986 & 0.024 \\
\hline & & & & & & & & & Bank & Mean & 0.990 & \\
\hline \multirow[t]{8}{*}{ HALKBANK } & 1 & 1 & 0.876 & 1 & & & & & & & 0.969 & 0.054 \\
\hline & & 1 & 0.890 & 1 & 1 & & & & & & 0.972 & 0.048 \\
\hline & & & 0.943 & 1 & 1 & 1 & & & & & 0.986 & 0.025 \\
\hline & & & & 1 & 1 & 1 & 1 & & & & 1 & 0 \\
\hline & & & & & 1 & 1 & 1 & 1 & & & 1 & 0 \\
\hline & & & & & & 1 & 1 & 1 & 1 & & 1 & 0 \\
\hline & & & & & & & 1 & 1 & 1 & 1 & 1 & 0 \\
\hline & & & & & & & & & Bank & Gean & 0.990 & \\
\hline \multirow[t]{8}{*}{ Türkiye İs Bankas1 } & 0.817 & 0.973 & 1 & 1 & & & & & & & 0.947 & 0.076 \\
\hline & & 0.973 & 1 & 1 & 1 & & & & & & 0.993 & 0.012 \\
\hline & & & 1 & 1 & 1 & 1 & & & & & 1 & 0 \\
\hline & & & & 1 & 1 & 1 & 1 & & & & 1 & 0 \\
\hline & & & & & 1 & 1 & 1 & 1 & & & 1 & 0 \\
\hline & & & & & & 1 & 1 & 1 & 0.993 & & 0.998 & 0.003 \\
\hline & & & & & & & 1 & 1 & 1 & 0.978 & 0.994 & 0.010 \\
\hline & & & & & & & & & Bank & Gean & 0.991 & \\
\hline \multirow[t]{8}{*}{ Vak1fBank } & 0.801 & 0.915 & 0.980 & 1 & & & & & & & 0.924 & 0.078 \\
\hline & & 0.915 & 0.934 & 0.959 & 1 & & & & & & 0.952 & 0.032 \\
\hline & & & 0.943 & 0.959 & 1 & 1 & & & & & 0.975 & 0.025 \\
\hline & & & & 0.955 & 1 & 1 & 1 & & & & 0.989 & 0.019 \\
\hline & & & & & 1 & 1 & 1 & 1 & & & 1 & 0 \\
\hline & & & & & & 1 & 1 & 1 & 1 & & 1 & 0 \\
\hline & & & & & & & 0.924 & 0.962 & 1 & 1 & 0.972 & 0.032 \\
\hline & & & & & & & & & Bank & Gean & 0.973 & \\
\hline \multirow[t]{8}{*}{ Yap1Kredi } & 0.998 & 0.944 & 0.989 & 1 & & & & & & & 0.983 & 0.023 \\
\hline & & 0.943 & 0.987 & 1 & 1 & & & & & & 0.982 & 0.024 \\
\hline & & & 0.976 & 0.987 & 1 & 1 & & & & & 0.991 & 0.010 \\
\hline & & & & 0.927 & 1 & 1 & 1 & & & & 0.982 & 0.032 \\
\hline & & & & & 1 & 1 & 1 & 1 & & & 1 & 0 \\
\hline & & & & & & 1 & 1 & 1 & 1 & & 1 & 0 \\
\hline & & & & & & & 0.934 & 1 & 1 & 1 & 0.983 & 0.029 \\
\hline & & & & & & & & & Bank & Mean & 0.989 & \\
\hline Average & 0.900 & 0.922 & 0.938 & 0.976 & 0.983 & 0.994 & 0.969 & 0.966 & 0.944 & 0.969 & & \\
\hline
\end{tabular}

